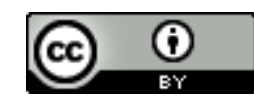

Esta obra está sob o direito de

Licença Creative Commons

Atribuição 4.0 Internacional.

\title{
O LÚDICO NA EDUCAÇÃO INDÍGENA
}

\author{
Marta Lúcia Silva Costal \\ Andrea Marques Vanderlei Fregadolli ${ }^{2}$ \\ Betijane Soares de Barros ${ }^{3}$ \\ Marcia Lucia Costa da Silva
}

\section{RESUMO}

Introdução: A criança está em fase de constante aprendizagem sobre o mundo em que está inserida, é um ser que depende do cuidado dos adultos para sobreviver e precisa se adaptar ao que solicita a sociedade. Trazendo essa realidade para a educação infantil indígena entende-se que essa criança possui uma capacidade de entendimento diferenciada e é de grande importância para o professor respeite o tempo que ela precisa para aprender, pois assim, reconhecendo a realidade dos seus alunos o professor fará um planejamento a partir dos problemas encontrados, realizando uma avaliação no processo de ensino-aprendizagem. Objetivo: analisar a concepção da ludicidade a fim de compreender os caminhos construídos para essa prática na educação infantil indígena. Metodologia: revisão sistemática integrativa. Resultados e Discussão: Considerando os critérios de inclusão estabelecidos durante a pesquisa foram selecionados 30 artigos que contemplavam a relação entre a ludicidade e educação infantil indígena. Assim, com a análise dos trabalhos científicos investigados obteve-se as seguintes categorias: a utilização da ludicidade como recurso pedagógico na sala de aula; a educação da criança indígena; a ludicidade na educação infantil indígena. Conclusão: é importante utilizar a ludicidade como recurso pedagógico na educação infantil indígena, uma vez que ela supre a necessidade da curiosidade e descoberta que a criança possui. Considerando que esta utilização, quando trabalhada de forma adequada, pode ser fundamentada tanto na formação educativa, quanto na formação cultural da criança indígena, entende-se que esta prática se torna, indiscutivelmente necessária no processo ensino-aprendizagem.

Descritores: Ludicidade. Educação infantil indígena. Brincadeiras e jogos indígenas.

\begin{abstract}
\footnotetext{
1 martaluciadir@gmail.com

2 deadoutorado@hotmail.com

3 bj-sb@hotmail.com

4 marciamg@live.com
}

Introduction: The child is in a phase of constant learning about the world in which he is inserted, he is a being who depends on the care of adults to survive and needs to adapt to what society requires. Bringing this reality to indigenous early childhood education, it is understood that this child has a differentiated understanding capacity and is of great importance for the teacher to respect the time he needs to learn, because thus, recognizing the reality of his students, the 
teacher will make a planning based on the problems encountered, carrying out an evaluation in the teaching-learning process. Objective: to analyze the concept of playfulness in order to understand the paths built for this practice in indigenous early childhood education. Methodology: systematic integrative review. Results and Discussion: Considering the inclusion criteria established during the research, 30 articles were selected that contemplated the relationship between playfulness and indigenous child education. Thus, with the analysis of the investigated scientific works, the following categories were obtained: the use of playfulness as a pedagogical resource in the classroom; the education of indigenous children; playfulness in indigenous children's education. Conclusion: it is important to use playfulness as a pedagogical resource in indigenous early childhood education, since it meets the need for the child's curiosity and discovery. Considering that this use, when properly worked, can be based on both educational and cultural training of indigenous children, it is understood that this practice becomes, arguably necessary in the teaching-learning process.

Descriptors: Playfulness. Indigenous child education. Indigenous games and games. 


\section{INTRODUÇÃO}

A criança está em fase de constante aprendizagem sobre o mundo em que está inserida, é um ser que depende do cuidado dos adultos para sobreviver e precisa se adaptar ao que solicita a sociedade. Nessa fase, necessita aprender tudo o que seja importante para sua sobrevivência.

Trazendo essa realidade para a educação infantil indígena entende-se que essa criança possui uma capacidade de entendimento diferenciada e é de grande importância para o professor respeite o tempo que ela precisa para aprender, pois assim, reconhecendo a realidade dos seus alunos o professor fará um planejamento a partir dos problemas encontrados, realizando uma avaliação no processo de ensino-aprendizagem. Assim, compreendese que na Educação Infantil indígena respeitar o tempo dessa criança é essencial para alcançar o sucesso desejado.

A sistematização dos conteúdos feita pelos professores em sala de aula não reflete o conhecimento de mundo (em constante transformação) trazido pelos educandos, continuando assim como metodologias focadas no resultado, na nota, que leva à aprovação ou à reprovação. A questão que mais envolve a problemática do processo de ensino-aprendizagem hoje na visão dos professores passa por como ensinar essa geração que se encontra tão envolta em necessidades afetivas, sociais, motoras e linguísticas e ao mesmo tempo tão vazia em habilidades que promovam reflexão e a construção do conhecimento.

É sabido que chamar a atenção das crianças na sala de aula não é uma tarefa impossível, embora em alguns momentos pode apresentar-se como algo desafiador. Nesse sentido, a ludicidade surge como ferramenta imprescindível nesse momento, visto que é possível utilizá-la de diferentes formas, tornando-a um recurso pedagógico em consonância com a orientação metodológica do trabalho.

Vivenciar a ludicidade em sala de aula é permitir favorecer ao mesmo tempo, o desenvolvimento da corporeidade, da capacidade de compartilhar significados, sentimentos, e de imaginar, na medida em que acabam por se constituir em jogos dramáticos, danças e imitações que exploram a gestualidade e a linguagem cênica.

O presente artigo insere-se nesse contexto, que através da revisão sistemática integrativa, objetiva analisar a concepção da ludicidade a fim de compreender os caminhos construídos para essa prática na educação infantil indígena.

A fim de elaborar tal reflexão teórica foi realizado um estudo fundamentando-se em leituras críticas dos artigos revisados dos seguintes autores: Melo (2019), Luckesi (2014), Domingues-Lopes (2015), Porto 
(2018), Antunes e Batista (2017), e Santana et al (2016) abordaram a temática da utilização da ludicidade como recurso pedagógico na sala de aula; Silva (2014), Andriolli e Faustino (2019), Troquez (2016), Grando (2014), Grando (2016), Ives-Felix e Nakayama (2018), Bergamaschi e Menezes (2016), Jankauskas et al (2015), Pinho e Tomazzetti (2017), Melo e Ribeiro (2019) e Almeida et al (2017) trataram sobre a educação da criança indígena e Silva et al (2015), Rodrigues (2018), Ramires e Mota (2018), Conti et al

\section{METODOLOGIA}

O presente estudo se desenvolveu por meio de uma revisão bibliográfica do tipo sistemática integrativa que adotou as seguintes etapas (detalhadas no quadro 02):

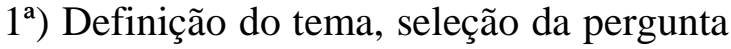
norteadora e escolha da estratégia de busca, descritores e bases de dados mais eficazes no levantamento das publicações; $2^{\mathrm{a}}$ ) Escolha dos critérios de inclusão e exclusão; $3^{\text {a }}$ ) Identificação dos estudos préselecionados e selecionados através da leitura dos agentes indexadores das publicações, como resumo, palavras-chave
(2017), Delle Piagge et al (2019), Mota e Ramires (2018), Tenório e Silva (2014), Faustino e Mota (2016), Martins et al (2019), Barros et al (2014), Conti et al (2018) e Figueiredo e Azevedo (2014) versaram acerca da ludicidade na educação infantil indígena.

Em suma toda a temática dos artigos estudados traz à reflexão o uso da ludicidade na educação infantil indígena, considerando que esta pode ser um instrumento pedagógico muito significativo e de grande valor social.

e título, bem como organização dos estudos pré-selecionados e identificação dos estudos selecionados; $4^{\mathrm{a}}$ ): Categorização dos estudos selecionados, com elaboração e uso da matriz de síntese, além de análise das informações, formação de uma biblioteca individual e avaliação crítica dos estudos selecionados; $5^{\text {a }}$ ) análise, interpretação e discussão dos resultados; $6^{a}$ ) Apresentação da revisão em formato de artigo, o qual contemple propostas para estudos futuros (BOTELHO; CUNHA; MACEDO, 2011; SCHMOELLER et al., 2011).

Quadro 1 - Detalhamento das etapas da Revisão Sistemática Integrativa.

\begin{tabular}{|c|c|l|}
\hline ETAPA & TÓPICOS DE CADA ETAPA & \multicolumn{1}{c|}{ DETALHAMENTO DE CADA TÓPICO } \\
\hline \multirow{2}{*}{$1^{\mathrm{a}}$} & \multicolumn{1}{|c|}{ Tema } & O Lúdico na Educação Indígena \\
\cline { 2 - 3 } & Pergunta norteadora & $\begin{array}{l}\text { De que forma a ludicidade é articulada no espaço escolar } \\
\text { infantil indígena? }\end{array}$ \\
\hline
\end{tabular}




\begin{tabular}{|c|c|c|}
\hline & Objetivo geral & $\begin{array}{l}\text { Analisar a concepção da ludicidade a fim de compreender os } \\
\text { caminhos construídos para essa prática na educação infantil } \\
\text { indígena. }\end{array}$ \\
\hline & Estratégias de busca & $\begin{array}{l}\text { Cruzamento de descritores por meio do operador boleano } \\
\text { AND; Uso de aspas nos politermos (descritor com mais de } \\
\text { um termo) para que a varredura de artigos científicos } \\
\text { contemplasse o termo exato; Uso de filtro do tipo data de } \\
\text { publicação. }\end{array}$ \\
\hline & Descritores livres e estruturados & $\begin{array}{l}\text { Ludicidade; } \\
\text { Educação infantil indígena; } \\
\text { Lúdico; } \\
\text { Brincadeiras e jogos indígenas. }\end{array}$ \\
\hline & Bibliotecas Virtuais & $\begin{array}{l}\text { Scientific Electronic Library Online (SciELO); } \\
\text { Google Acadêmico; Revistas Eletrônicas. }\end{array}$ \\
\hline $2^{a}$ & Período de coleta dos dados & Agosto e outubro de 2019. \\
\hline & Critérios de inclusão & $\begin{array}{l}\text { Texto completo (disponível/free) do tipo: artigo original, } \\
\text { artigo de revisão, artigo na imprensa, recurso, editorial, } \\
\text { perspectiva e pesquisa transacional; Publicação (2014-2019). }\end{array}$ \\
\hline & Critérios de exclusão & $\begin{array}{l}\text { Livros, monografias, Trabalho de Conclusão de Curso, } \\
\text { Resumos, Relatórios, Teses e Dissertações; Artigos que não } \\
\text { contemplavam a relação entre a interculturalidade e educação } \\
\text { indígena. }\end{array}$ \\
\hline $3^{\mathrm{a}}$ & $\begin{array}{l}\text { Número de trabalhos selecionados } \\
\text { para revisão sistemática integrativa } \\
\text { a partir da leitura dos agentes } \\
\text { indexadores das publicações } \\
\text { (resumo, palavras-chave e título) e } \\
\text { resultados, os quais deveriam } \\
\text { conter os descritores utilizados } \\
\text { nesse estudo } \\
\end{array}$ & 30 trabalhos \\
\hline $4^{\mathrm{a}}$ & $\begin{array}{l}\text { Categorias obtidas com a análise } \\
\text { dos trabalhos científicos } \\
\text { investigados }\end{array}$ & $\begin{array}{l}\text { - A utilização da ludicidade como recurso pedagógico na sala } \\
\text { de aula; } \\
\text { - A educação da criança indígena; } \\
\text { - A ludicidade na educação infantil indígena. }\end{array}$ \\
\hline $5^{a}$ & $\begin{array}{l}\text { Análise, interpretação e discussão } \\
\text { dos resultados }\end{array}$ & Ver em "Resultados e Discussão" \\
\hline $6^{\mathrm{a}}$ & $\begin{array}{l}\text { Apresentação da revisão em } \\
\text { formato de artigo, o qual } \\
\text { contemple propostas para estudos } \\
\text { futuros }\end{array}$ & Esse Artigo completo \\
\hline
\end{tabular}

Fonte: elaborada pela autora.

\section{Resultados e Discussão}

\section{Considerando os critérios de} inclusão estabelecidos durante a pesquisa foram selecionados 30 artigos que contemplavam a relação entre a interculturalidade e educação indígena, conforme descritos resumidamente no quadro 02.

Quadro 02 - Levantamento de Publicações Científicas de Acordo com os Critérios de Inclusão.

\begin{tabular}{|c|c|c|c|c|c|}
\hline $\mathrm{N}^{\mathrm{o}}$ & CITAÇÃ̃O & TEMA & ANO & $\begin{array}{c}\text { OBJETIVO DO } \\
\text { ESTUDO }\end{array}$ & $\begin{array}{c}\text { CONCLUSÃO DO } \\
\text { ESTUDO }\end{array}$ \\
\hline
\end{tabular}




\begin{tabular}{|c|c|c|c|c|c|}
\hline 1 & $\begin{array}{l}\text { ANTUNES, } P . ; \\
\text { BATISTA, F. M. R. }\end{array}$ & $\begin{array}{c}\text { Brincar de } \\
\text { aprender: a } \\
\text { ludicidade como } \\
\text { recurso didático na } \\
\text { educação infantil }\end{array}$ & 2017 & $\begin{array}{l}\text { Trabalhar a inserção } \\
\text { da criança no mundo } \\
\text { pedagógico por meio } \\
\text { das atividades lúdicas } \\
\text { e sua interação no } \\
\text { processo ensino- } \\
\text { aprendizagem da } \\
\text { educação infantil. }\end{array}$ & $\begin{array}{l}\text { Os professores e alunos } \\
\text { devem trabalhar visando } \\
\text { o desenvolvimento de } \\
\text { atividades lúdicas } \\
\text { voltadas para uma } \\
\text { educação complexa, } \\
\text { trabalhando diretamente } \\
\text { seus conceitor no } \\
\text { processo ensino- } \\
\text { aprendizagem, } \\
\text { envolvendo a ludicidade } \\
\text { por meio de jogos e } \\
\text { brincadeiras que } \\
\text { conceituem a prática } \\
\text { pedagógica, a qual deve } \\
\text { se efetivar em sala de } \\
\text { aula, através de } \\
\text { estratégias que utilizem } \\
\text { materiais } \\
\text { contribuam para que } \\
\text { ensino. }\end{array}$ \\
\hline 2 & $\begin{array}{l}\text { BARROS, J. L. C. et } \\
\text { al. }\end{array}$ & $\begin{array}{l}\text { O brincar das } \\
\text { crianças Sataré- } \\
\text { Mawé e suas } \\
\text { relações } \\
\text { interculturais com } \\
\text { a educação escolar } \\
\text { indígena }\end{array}$ & 2014 & 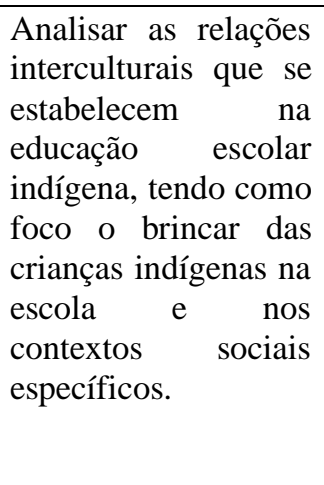 & $\begin{array}{l}\text { A educação das crianças } \\
\text { indígenas possui } \\
\text { características } \\
\text { diferenciadas, } \\
\text { constituindo um espaço } \\
\text { de trocas, respeito ao } \\
\text { modo de vida dos } \\
\text { indígenas, seus valores, } \\
\text { seus costumes e suas } \\
\text { brincadeirase, sobretudo } \\
\text { enquanto possibilidades } \\
\text { da interculturalidade. }\end{array}$ \\
\hline 3 & $\begin{array}{l}\text { DOMINGUES- } \\
\text { LOPES, et al. }\end{array}$ & $\begin{array}{l}\text { O lúdico em } \\
\text { questão: } \\
\text { brinquedos e } \\
\text { brincadeiras } \\
\text { indígenas }\end{array}$ & 2015 & $\begin{array}{l}\text { Versar } \\
\text { brinquedos, sobre } \\
\text { melhor, ou } \\
\text { lúdico-infantis, } \\
\text { encontlios } \\
\text { acervo etnográfico do } \\
\text { Laboratório do } \\
\text { Antropologia Arthur } \\
\text { Napoleão Figueiredo } \\
\text { da Universidade } \\
\text { Federal do Pará. }\end{array}$ & $\begin{array}{l}\text { O ato de brincar } \\
\text { evidencia a liberdade das } \\
\text { crianças indígenas no } \\
\text { processo de (re) } \\
\text { apropriação dos valores } \\
\text { culturais, entre os quais, } \\
\text { o "saber da criança" } \\
\text { mescla-se ao "saber } \\
\text { sobre a criança" para } \\
\text { construir a noção nativa } \\
\text { do "saber tornar-se } \\
\text { criança", condições } \\
\text { antropológicas que } \\
\text { reclamam a tradução } \\
\text { intercultural dos direitos } \\
\text { voltados às crianças } \\
\text { indígenas. }\end{array}$ \\
\hline 4 & SILVA, R. C. & $\begin{array}{c}\text { Participação e } \\
\text { aprendizagem na } \\
\text { educação da } \\
\text { criança indígena. }\end{array}$ & 2014 & $\begin{array}{l}\text { Estabelecer um } \\
\text { diálogo mais estreito } \\
\text { entre os campos da } \\
\text { educação e da } \\
\text { antropologia, no que } \\
\text { se refere a } \\
\text { investigação sobre a } \\
\text { aprendizagem da } \\
\text { criança indígena. }\end{array}$ & $\begin{array}{l}\text { Na ação e na } \\
\text { participação das crianças } \\
\text { em seu grupo familiar e } \\
\text { comunitário, reconhece- } \\
\text { se que os meninos } \\
\text { Xakriabá, na medida em } \\
\text { que aprendem, } \\
\text { desempenham um papel } \\
\text { fundamental nal }\end{array}$ \\
\hline
\end{tabular}




\begin{tabular}{|c|c|c|c|c|c|}
\hline & & & & & $\begin{array}{l}\text { manutenção do seu } \\
\text { próprio grupo. }\end{array}$ \\
\hline 5 & MELO, J. C. & $\begin{array}{l}\text { A função do lúdico } \\
\text { na transição da } \\
\text { educação infantil } \\
\text { para o primeiro ano } \\
\text { do ensino } \\
\text { fundamental }\end{array}$ & 2019 & 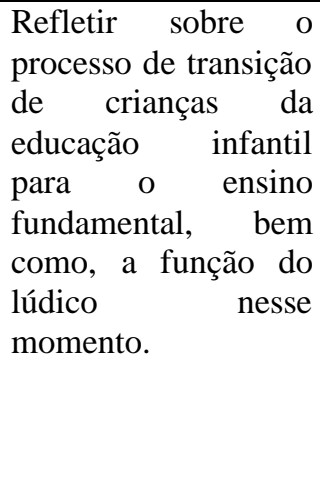 & $\begin{array}{l}\text { A promoção } \\
\text { atividades lúdicas no } \\
\text { processo de transição } \\
\text { entre a primeira e a } \\
\text { segunda etapa de } \\
\text { educação } \\
\text { contribui de forma } \\
\text { significativa para o } \\
\text { ensino e a aprendizagem } \\
\text { das crianças nos } \\
\text { aspectos cognitivo e } \\
\text { motor. }\end{array}$ \\
\hline 6 & $\begin{array}{l}\text { ANDRIOLLI, L. R.; } \\
\text { FAUSTINO, R. C. }\end{array}$ & $\begin{array}{c}\text { Vivências de } \\
\text { crianças indígenas } \\
\text { Kaingang na } \\
\text { cidade: elementos } \\
\text { para a } \\
\text { aprendizagem e o } \\
\text { desenvolvimento. }\end{array}$ & 2019 & $\begin{array}{lr}\text { Discutir } & \text { as } \\
\text { aprendizagens das } \\
\text { crianças, tanto na } \\
\text { instituição escolar de } \\
\text { Educação Infantil, na } \\
\text { terra indígena de } \\
\text { origem, como na } \\
\text { cidade, onde, } \\
\text { periodicamente, } \\
\text { vivenciam diversas } \\
\text { experiencias e } \\
\text { interações. }\end{array}$ & $\begin{array}{l}\text { Para os Kaingang, tanto } \\
\text { enviar as crianças } \\
\text { pequenas à escola, como } \\
\text { garantir a participação } \\
\text { delas em todas as } \\
\text { atividades familiares, } \\
\text { são ações importantes } \\
\text { pois representam } \\
\text { fecundos espaços de } \\
\text { aprendizagem a e } \\
\text { desenvolvimento infantil } \\
\text { indígena. }\end{array}$ \\
\hline 7 & PORTO, S. G. S. & $\begin{array}{l}\text { Ludicidade: um } \\
\text { caminho para } \\
\text { ressignificar a } \\
\text { prática pedagógica } \\
\text { e o } \\
\text { desenvolvimento } \\
\text { da criança na } \\
\text { educação infantil. }\end{array}$ & 2018 & $\begin{array}{lr}\text { Analisar } & \text { a } \\
\text { importância } & \text { da } \\
\text { ludicidade } & \text { na } \\
\text { aprendizagem e } & \text { no } \\
\text { desenvolvimento dos } \\
\text { alunos da } & \text { educação } \\
\text { infantil, } & \text { buscando } \\
\text { identificar } & \text { nos } \\
\text { estudos analisados de } \\
\text { que forma } & \text { as } \\
\text { atividades r lúdicas } \\
\text { auxiliam } & \text { no } \\
\text { aprendizado } & \text { dessas } \\
\text { crianças. } & \end{array}$ & $\begin{array}{l}\text { Observou-se que os } \\
\text { jogos, as brincadeiras e } \\
\text { os brinquedos tem uma } \\
\text { importância } \\
\text { fundamental } \\
\text { significativa } \\
\text { desenvolvimento } \\
\text { integral das crianças da } \\
\text { educação infantil, uma } \\
\text { vez que as atividades } \\
\text { lúdicas desenvolvem a } \\
\text { concentração, } \\
\text { criatividade, a } \\
\text { interações sociais, a } \\
\text { comunicação } \\
\text { aprendizado cognitivo } \\
\text { de forma prazerosa e } \\
\text { significativa. }\end{array}$ \\
\hline 8 & $\begin{array}{l}\text { TROQUEZ, M. C. } \\
\text { C. }\end{array}$ & $\begin{array}{l}\text { Educação infantil } \\
\text { na legislação e na } \\
\text { produção do } \\
\text { conhecimento }\end{array}$ & 2016 & \begin{tabular}{lr}
\multicolumn{2}{l}{ Investigar } \\
pressupostos legais e \\
teóricos & sobre a \\
educação & infantil \\
indígena, & como \\
primeira & etapa da \\
educação & básica \\
nacional. &
\end{tabular} & $\begin{array}{l}\text { A pesquisa evidenciou, } \\
\text { entre outros resultados, } \\
\text { que, embora a educação } \\
\text { infantil seja um direito } \\
\text { subjetivo da criança, } \\
\text { para a educação indígena } \\
\text { é facultativar } \mathrm{Na} \\
\text { produção } \\
\text { conhecimento, do } \\
\text { evidenciou grande } \\
\text { contribuição de estudos } \\
\text { da antropologia da } \\
\text { criança para o } \\
\text { conhecimento das } \\
\text { especificidades das } \\
\text { crianças em diferentes }\end{array}$ \\
\hline
\end{tabular}




\begin{tabular}{|c|c|c|c|c|c|}
\hline & & & & & $\begin{array}{l}\text { grupos étnicos. Contudo, } \\
\text { no que diz respeito à } \\
\text { especificidade } \\
\text { educação de crianças } \\
\text { indígenas } \\
\text { instituições de educação } \\
\text { infantil, o estufo aponta } \\
\text { muitas questões para o } \\
\text { debate/estudos e } \\
\text { evidencia a necessidade } \\
\text { de pesquisas de campo } \\
\text { para o conhecimento de } \\
\text { cada realidade e das } \\
\text { demandas por educação } \\
\text { infantil de acordo com } \\
\text { cada povo ou grupo } \\
\text { étnico. }\end{array}$ \\
\hline 9 & GRANDO, B. S. & $\begin{array}{c}\text { Infância, } \\
\text { brincadeiras e } \\
\text { brinquedos em } \\
\text { comunidades } \\
\text { indígenas } \\
\text { brasileiras }\end{array}$ & 2014 & 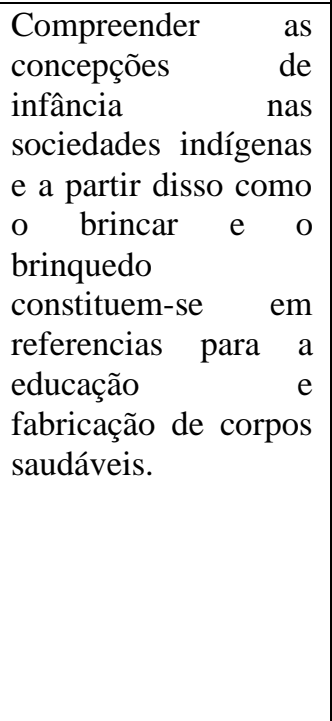 & $\begin{array}{l}\text { No processo de aprender } \\
\text { e ensinar, o brincar é } \\
\text { parte do reconhecimento } \\
\text { da autonomia da criança } \\
\text { e estão atrelados ao } \\
\text { papel que esta assume na } \\
\text { sociabilidade e } \\
\text { mediação pertinentes ao } \\
\text { seu grupo social. Neste } \\
\text { processo, aparentemente } \\
\text { despretensioso e lúdico, } \\
\text { a criança vai dando } \\
\text { sentido e significado a } \\
\text { sua forma única de ser e } \\
\text { estar no mundo, como } \\
\text { parte de uma cosmologia } \\
\text { que é própria de cada } \\
\text { sociedade indígena. }\end{array}$ \\
\hline 10 & $\begin{array}{l}\text { ALMEIDA, J. A. et } \\
\text { al. }\end{array}$ & $\begin{array}{c}\text { Infância e } \\
\text { educação infantil } \\
\text { indígena: um } \\
\text { estudo da criança } \\
\text { Apinajé }\end{array}$ & 2017 & $\begin{array}{l}\text { Conhecer a ação das } \\
\text { escolas dessas } \\
\text { aldeias, alcançando } \\
\text { as práticas } \\
\text { pedagógicas, } \\
\text { currículo e a relação } \\
\text { professor-aluno, em } \\
\text { duas classes de } \\
\text { alfabetização, } \\
\text { considerando o valor } \\
\text { da cultura desse } \\
\text { povo, também dentro } \\
\text { da educação escolar. }\end{array}$ & $\begin{array}{l}\text { As escolas precisam } \\
\text { estabelecer relações } \\
\text { mais estreitas com a vida } \\
\text { e o cotidiano da aldeia. E } \\
\text { as práticas culturais das } \\
\text { crianças, nomeadamente } \\
\text { folguedos e brincadeiras, } \\
\text { podem ser aportes } \\
\text { facilitadores de uma } \\
\text { educação diferenciada, } \\
\text { considerando ser esta } \\
\text { uma conquista dos povos } \\
\text { indígenas brasileiros, } \\
\text { garantida por } \\
\text { instrumentos jurídicos } \\
\text { nacionais } \\
\text { internacionais. }\end{array}$ \\
\hline 11 & GRANDO, B. S. & $\begin{array}{c}\text { Educação da } \\
\text { criança indígena e } \\
\text { educação infantil } \\
\text { em Mato Grosso: } \\
\text { uma questão para o } \\
\text { debate }\end{array}$ & 2016 & $\begin{array}{lrr}\text { Refletir } & \text { sobre } & \text { a } \\
\text { educação } & \text { escolar } \\
\text { indígena e } & \text { sua relação } \\
\text { com a } & \text { educação } \\
\text { pretendida } & \text { por } & \text { cada } \\
\text { povo, } & & \\
\text { problematizando as } \\
\text { políticas }\end{array}$ & $\begin{array}{l}\text { Ficou evidenciado nos } \\
\text { estudos o protagonismo } \\
\text { e autonomia da criança a } \\
\text { partir das formas de } \\
\text { educar e garantir a vida } \\
\text { coletiva como um direito } \\
\text { coletivo dos povos } \\
\text { indígenas, explicitados }\end{array}$ \\
\hline
\end{tabular}




\begin{tabular}{|c|c|c|c|c|c|}
\hline & & & & $\begin{array}{llr}\text { educacionais } & \text { e } & \text { a } \\
\text { formação } & & \text { de } \\
\text { professores. } & & \\
\end{array}$ & $\begin{array}{l}\text { na Constituição } \\
\text { brasileira e na LDB. }\end{array}$ \\
\hline 12 & $\begin{array}{l}\text { FIGUEIREDO, L. } \\
\text { M. S.; AZEVEDO, } \\
\text { L. F. }\end{array}$ & $\begin{array}{c}\text { Jogos e } \\
\text { brincadeiras } \\
\text { indígenas em Mato } \\
\text { Grosso }\end{array}$ & 2014 & $\begin{array}{lr}\text { Descrever e refletir } \\
\text { sobre jogos } \\
\text { brincadeiras } \\
\text { Estado do } \\
\text { Grosso. }\end{array}$ & $\begin{array}{l}\text { As brincadeiras infantis } \\
\text { nas culturas indígenas de } \\
\text { Mato Grosso mostram o } \\
\text { aprendizado do contexto } \\
\text { (cultural e físico) como } \\
\text { fatores formadores de } \\
\text { identidades em cada } \\
\text { etnia, por meio de jogos } \\
\text { e brincadeiras. }\end{array}$ \\
\hline 13 & SILVA, M. et al. & $\begin{array}{l}\text { Brinquedos e } \\
\text { brincadeiras } \\
\text { indígenas } \\
\text { Kaingangs: } \\
\text { transfiguração } \\
\text { entre gerações }\end{array}$ & 2015 & $\begin{array}{l}\text { Diagnosticar } \\
\text { brinquedos } \\
\text { brincadeiras antigas } \\
\text { que os indígenas } \\
\text { Kaingangs da aldeia } \\
\text { Pinhalzinho tinham } \\
\text { na época de criança e } \\
\text { as mudanças que } \\
\text { ocorreram para os } \\
\text { dias atuais. }\end{array}$ & $\begin{array}{l}\text { As respostas indicaram } \\
\text { que os brinquedos, que } \\
\text { antes eram } \\
\text { confeccionados, } \\
\text { passaram a ser } \\
\text { substituídos por } \\
\text { brinquedos comprados } \\
\text { nos centros urbanos. } \\
\text { Observou-se também } \\
\text { que a brincadeira de } \\
\text { maior popularidade na } \\
\text { comunidade estudada foi } \\
\text { o futebol, com a } \\
\text { mudança que atualmente } \\
\text { é jogado com maior } \\
\text { competitividade. } \\
\text { Através dos resultados, } \\
\text { percebeu-se que com o } \\
\text { contato com os } \\
\text { brinquedos tecnológicos } \\
\text { o Kaingang vem } \\
\text { perdendo costumes que } \\
\text { eram passados de } \\
\text { geração a } \\
\text { consequentemente, } \\
\text { dissipando sua cultura. }\end{array}$ \\
\hline 14 & RODRIGUES, W. & $\begin{array}{l}\text { Relacionando } \\
\text { ludicidade e } \\
\text { matemática na } \\
\text { infância indígena }\end{array}$ & 2018 & $\begin{array}{l}\text { Relacionar as } \\
\text { brincadeiras das } \\
\text { crianças indígenas, os } \\
\text { conceitos sobre } \\
\text { ludicidade e algumas } \\
\text { noções matemáticas } \\
\text { básicas utilizadas } \\
\text { pelas crianças. }\end{array}$ & $\begin{array}{l}\text { A introdução de } \\
\text { conceitos matemáticos } \\
\text { na vida de crianças } \\
\text { indígenas da primeira } \\
\text { infância pode ajudar no } \\
\text { desenvolvimento } \\
\text { intelectual, emocional e } \\
\text { social de tais crianças. } \\
\text { Ela ainda pode ajudar na } \\
\text { tomada de decisões, na } \\
\text { compreensão de } \\
\text { determinados padrões e } \\
\text { na realização de diversas } \\
\text { atividades cotidianas. }\end{array}$ \\
\hline 15 & $\begin{array}{l}\text { MOTA, L. K. L.; } \\
\text { RAMIRES, C. R. }\end{array}$ & $\begin{array}{l}\text { Educação infantil } \\
\text { indígena e a } \\
\text { ludicidade: a } \\
\text { percepção de } \\
\text { agentes escolares } \\
\text { na aprendizagem } \\
\text { da criança }\end{array}$ & 2018 & $\begin{array}{l}\text { Compreender } \\
\text { percepção de pais e } \\
\text { professores sobre a } \\
\text { importância da arte } \\
\text { lúdica no processo } \\
\text { aprendizagem na } \\
\text { educação infantil } \\
\text { indígena em pré- }\end{array}$ & 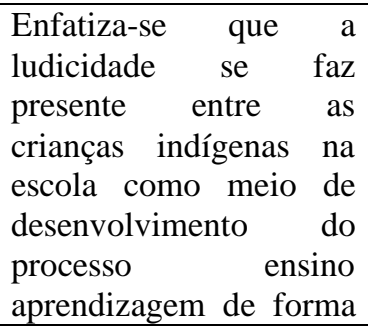 \\
\hline
\end{tabular}




\begin{tabular}{|c|c|c|c|c|c|}
\hline & & & & $\begin{array}{lr}\text { escola } & \text { na } \\
\text { comunidade indígena } \\
\text { Ticuna de Porto } \\
\text { Cordeirinho r em } \\
\text { Benjamin Constant - } \\
\text { AM. }\end{array}$ & $\begin{array}{l}\text { mais prazerosa. Mas, a } \\
\text { ludicidade apesar de } \\
\text { estar amparada } \\
\text { legalmente nas políticas } \\
\text { públicas educacionais } \\
\text { ainda é pouco praticada } \\
\text { na educação infantil } \\
\text { indígena. }\end{array}$ \\
\hline 16 & $\begin{array}{l}\text { RAMIRES, C. R.; } \\
\text { MOTA, L. K. L. }\end{array}$ & $\begin{array}{l}\text { Educação infantil } \\
\text { indígena e a } \\
\text { formação de } \\
\text { professores: } \\
\text { aspectos legais e a } \\
\text { importância da } \\
\text { qualidade } \\
\text { educacional pré- } \\
\text { escolar na voz } \\
\text { docente }\end{array}$ & 2018 & 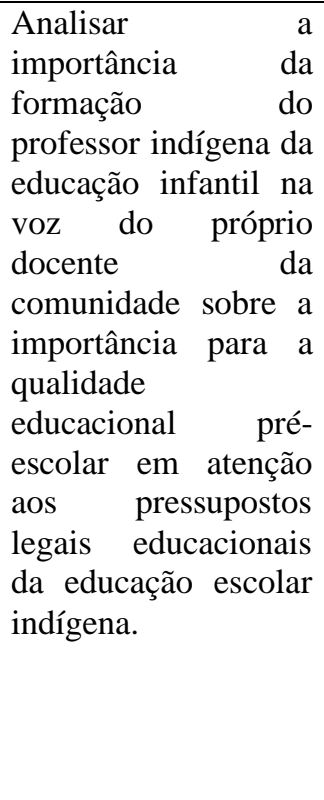 & $\begin{array}{l}\text { Os resultados versam } \\
\text { sobre o interesse da } \\
\text { comunidade indígena } \\
\text { em querer a educação } \\
\text { infantil na comunidade, } \\
\text { mesmo a educação } \\
\text { infantil sendo opcional } \\
\text { de acordo com os } \\
\text { parâmetros } \\
\text { constitucionais legais. } \\
\text { Os professores tem } \\
\text { interesse e há } \\
\text { necessidade de formação } \\
\text { inicial, continuada e em } \\
\text { serviço para o professor } \\
\text { indígena, tendo em vista } \\
\text { a melhoria da qualidade } \\
\text { da educação infantil no } \\
\text { contexto indígena } \\
\text { Ticuna. }\end{array}$ \\
\hline 17 & CONTI, K. C. et al. & $\begin{array}{l}\text { Criação de jogos } \\
\text { no contexto } \\
\text { indígena: o cabo de } \\
\text { guerra numérico }\end{array}$ & 2017 & $\begin{array}{l}\text { Descrever a criação } \\
\text { de um jogo, o cabo de } \\
\text { guerra numérico, por } \\
\text { um dos estudantes do } \\
\text { curso de formação } \\
\text { intercultural de } \\
\text { educadores } \\
\text { indígenas, habilitação } \\
\text { em matemática, da } \\
\text { UFMG. }\end{array}$ & $\begin{array}{l}\text { Por apresentar jogadas } \\
\text { que exigiam estratégias } \\
\text { matemáticas o jogo } \\
\text { mostrou-se uma } \\
\text { possibilidade } \\
\text { interessante para o } \\
\text { ensino de matemática e } \\
\text { também um canal para a } \\
\text { avaliação dos saberes e } \\
\text { das práticas indígenas. }\end{array}$ \\
\hline 18 & $\begin{array}{l}\text { FAUSTINO, K. C.; } \\
\text { MOTA, L. T. }\end{array}$ & $\begin{array}{l}\text { Crianças indígenas: } \\
\text { o papel dos jogos, } \\
\text { das brincadeiras e } \\
\text { da imitação na } \\
\text { aprendizagem e no } \\
\text { desenvolvimento. }\end{array}$ & 2016 & $\begin{array}{l}\text { Apresentar e discutir } \\
\text { alguns estudos atuais } \\
\text { referentes à infância } \\
\text { indígena } \\
\text { experiências } \\
\text { registradas de ações } \\
\text { desenvolvidas junto } \\
\text { aos Kaingang, } \\
\text { Guarani e Xetá no } \\
\text { Estado do Paraná no } \\
\text { período de } 2012 \text { a } \\
\text { 2014. }\end{array}$ & $\begin{array}{l}\text { A maneira como é } \\
\text { pensada, planejada e } \\
\text { conduzida a educação } \\
\text { escolar indígena, de } \\
\text { forma geral no Brasil, } \\
\text { destina pouco espaço } \\
\text { para serem considerado } \\
\text { os saberes e as vivencias } \\
\text { das crianças, suas } \\
\text { brincadeiras, suas } \\
\text { diferentes maneiras de } \\
\text { interação } \\
\text { aprendizagem. }\end{array}$ \\
\hline 19 & $\begin{array}{l}\text { SANTANA, F. M. } \\
\text { N. et al. }\end{array}$ & $\begin{array}{l}\text { Ludicidade e o } \\
\text { contexto cultural } \\
\text { diversificado: } \\
\text { contribuições e } \\
\text { desafios no } \\
\text { processo ensinar e } \\
\text { aprender }\end{array}$ & 2016 & $\begin{array}{l}\text { Tratar sobre a } \\
\text { ludicidade no } \\
\text { processo do aprender, } \\
\text { reunindo dados que } \\
\text { indiquem conceitos e } \\
\text { concepções sobre o } \\
\text { tema proposto. }\end{array}$ & $\begin{array}{l}\text { Dos resultados } \\
\text { apresentados destacam- } \\
\text { se o conceito e a } \\
\text { relevância da ludicidade } \\
\text { no processo educacional } \\
\text { como meio de revitalizar } \\
\text { a própria cultura na qual } \\
\text { o educando está } \\
\text { inserido. }\end{array}$ \\
\hline
\end{tabular}




\begin{tabular}{|c|c|c|c|c|c|}
\hline 20 & LUCKESI, C. & $\begin{array}{l}\text { Ludicidade e } \\
\text { formação do } \\
\text { educador }\end{array}$ & 2014 & $\begin{array}{l}\text { Apresentar o trabalho } \\
\text { de dois temas: o que é } \\
\text { ludicidade e a } \\
\text { formação do } \\
\text { educador para ensinar } \\
\text { de modo lúdico. }\end{array}$ & $\begin{array}{l}\text { Ludicidade é } \\
\text { compreender como } \\
\text { experiencia interna de } \\
\text { inteireza e plenitude por } \\
\text { parte do sujeito. Para } \\
\text { ensinar ludicamente, o } \\
\text { educador necessita } \\
\text { cuidar-se } \\
\text { emocionalmente e, } \\
\text { cognitivamente, adquirir } \\
\text { as habilidades } \\
\text { necessárias para } \\
\text { conduzir o ensino de tal } \\
\text { forma que subsidie uma } \\
\text { aprendizagem lúdica.55 }\end{array}$ \\
\hline 21 & CONTI, K. C. et al. & $\begin{array}{l}\text { Uso de jogos } \\
\text { matemáticos como } \\
\text { proposta } \\
\text { pedagógica num } \\
\text { contexto de } \\
\text { formação } \\
\text { intercultural para } \\
\text { professores } \\
\text { indígenas }\end{array}$ & 2018 & $\begin{array}{l}\text { Descrever } \\
\text { utilização do jogo } \\
\text { trinca-espinhas e a } \\
\text { criação do jogo cabo } \\
\text { de guerra numérica. }\end{array}$ & $\begin{array}{l}\text { As descrições dos jogos } \\
\text { foram realizadas a partir } \\
\text { de alguns momentos que } \\
\text { analisamos serem } \\
\text { produtivos durante as } \\
\text { aulas na universidade e } \\
\text { no território indígena. } \\
\text { Nesse sentido, } \\
\text { consideramos que essas } \\
\text { atividades } \\
\text { oportunizaram } \\
\text { momentos } \\
\text { aprendizagem a partir de } \\
\text { uma abordagem criativa, } \\
\text { lúdica e divertida. }\end{array}$ \\
\hline 22 & $\begin{array}{l}\text { PINHO, V. } \\
\text { TOMA; } \\
\text { M. }\end{array}$ & $\begin{array}{l}\text { Infâncias, saberes e } \\
\text { diversidade: um } \\
\text { diálogo com a } \\
\text { educação infantil }\end{array}$ & 2017 & $\begin{array}{l}\text { Abordar o tema da } \\
\text { educação infantil na } \\
\text { perspectiva mais } \\
\text { ampla da democracia, } \\
\text { da diversidade de } \\
\text { populações infantis e } \\
\text { de saberes sobre elas. }\end{array}$ & $\begin{array}{l}\text { Preconiza-se que a } \\
\text { educação infantil de } \\
\text { crianças negras e } \\
\text { indígenas, } \\
\text { principalmente, deve } \\
\text { servir ao propósito de } \\
\text { efetivação da educação } \\
\text { democrática como } \\
\text { garantida do acesso } \\
\text { universal, da qualidade } \\
\text { das práticas educativas e } \\
\text { da garantia dos direitos à } \\
\text { diversidade de } \\
\text { experiências sociais e da } \\
\text { diferença, dispondo-se a } \\
\text { desnudar a sua história e } \\
\text { valorizar a sua cultura } \\
\text { com os sentidos de } \\
\text { ser/pertencer no diálogo } \\
\text { da e para a diversidade. }\end{array}$ \\
\hline 23 & MARTINS, R. et al. & $\begin{array}{c}\text { O resgate das } \\
\text { memorias do jogo } \\
\text { e brincadeiras de } \\
\text { uma comunidade } \\
\text { indígena }\end{array}$ & 2019 & $\begin{array}{l}\text { Identificar o resgate } \\
\text { das atividades físicas } \\
\text { de lazer entre pais e } \\
\text { filhos de uma } \\
\text { comunidade } \\
\text { indígena. }\end{array}$ & $\begin{array}{l}\text { Foi possível constatar } \\
\text { que os jogos e } \\
\text { brincadeiras recordados } \\
\text { por jovens indígenas e } \\
\text { com descendência são } \\
\text { diferentes das atividades } \\
\text { culturais desta } \\
\text { comunidade de } \\
\text { atualmente. Os jovens da } \\
\text { geração atual, tem pouco }\end{array}$ \\
\hline
\end{tabular}




\begin{tabular}{|c|c|c|c|c|c|}
\hline & & & & & $\begin{array}{l}\text { conhecimento e prática } \\
\text { de jogos e brincadeiras } \\
\text { de sua própria cultura, } \\
\text { assim como de outras } \\
\text { etnias brasileiras. }\end{array}$ \\
\hline 24 & $\begin{array}{l}\text { BERGAMASCHI, } \\
\text { M. A.; MENEZES, } \\
\text { A. L. T. }\end{array}$ & $\begin{array}{l}\text { Crianças indígenas, } \\
\text { educação, escola e } \\
\text { interculturalidade }\end{array}$ & 2016 & $\begin{array}{l}\text { Apresentar reflexões } \\
\text { produzidas a partir da } \\
\text { convivência com o } \\
\text { povo Guarani, } \\
\text { buscando } \\
\text { compreender seus } \\
\text { processos próprios de } \\
\text { educação r que } \\
\text { envolvem as crianças } \\
\text { e são responsáveis } \\
\text { pela formação da } \\
\text { pessoa. }\end{array}$ & $\begin{array}{l}\text { Constatou-se uma } \\
\text { educação que considera } \\
\text { a dimensão espiritual, a } \\
\text { dimensão coletiva de } \\
\text { uma comunidade que se } \\
\text { mostra implicada como a } \\
\text { formação da pessoa e } \\
\text { uma dimensão } \\
\text { individual, em que cada } \\
\text { um se responsabiliza por } \\
\text { si, imbuído por uma } \\
\text { busca e por um } \\
\text { caminhar. }\end{array}$ \\
\hline 25 & $\begin{array}{ll}\text { MELO, } & \text { A.; } \\
\text { RIBEIRO, D. }\end{array}$ & $\begin{array}{l}\text { Interculturalidade e } \\
\text { educação infantil: } \\
\text { reflexões sobre } \\
\text { diferenças culturais } \\
\text { na infância }\end{array}$ & 2019 & $\begin{array}{l}\text { Apresentar } \\
\text { interculturalidade } \\
\text { crítica como } \\
\text { ferramenta } \\
\text { pedagógica que deve } \\
\text { ser central na } \\
\text { constituição dos } \\
\text { cenários e contextos } \\
\text { em educação infantil. }\end{array}$ & $\begin{array}{l}\text { Construir práticas } \\
\text { pedagógicas } \\
\text { interculturais, na } \\
\text { educação infantil, leva a } \\
\text { ampliar o olhar para a } \\
\text { diversidade de culturas } \\
\text { da sociedade e não } \\
\text { apenas de cada turma. } \\
\text { Traz implicações ao } \\
\text { currículo e a toda a } \\
\text { organização } \\
\text { institucional, pois a } \\
\text { diversidade deve ser o } \\
\text { eixo que permeia tudo } \\
\text { acontece nas instituições } \\
\text { educativas e não ser } \\
\text { apenas um adendo que } \\
\text { deve ser trabalhado de } \\
\text { vez em quando. }\end{array}$ \\
\hline 26 & $\begin{array}{l}\text { GODOY, } \\
\text { FERREIRA, E. }\end{array}$ & $\begin{array}{c}\text { O universo cultural } \\
\text { da criança Guarani } \\
\text { Mbya e a presença } \\
\text { dos centros } \\
\text { educacionais e } \\
\text { culturais indígenas }\end{array}$ & 2014 & $\begin{array}{l}\text { Descrever o universo } \\
\text { cultural da criança } \\
\text { Guarani Mbya e a } \\
\text { presença dos centros } \\
\text { educacionais e } \\
\text { culturas indígenas } \\
\text { cecis, nas aldeias de } \\
\text { São Paulo. }\end{array}$ & $\begin{array}{l}\text { Define-se uma proposta } \\
\text { pedagógica mantida pela } \\
\text { Prefeitura Municipal } \\
\text { comprometida com os } \\
\text { critérios legais de } \\
\text { diversidade e de } \\
\text { interculturalidade da } \\
\text { educação indígena. O } \\
\text { conteúdo dos projetos e } \\
\text { das práticas educativas } \\
\text { situam a } \\
\text { comprometimento com a } \\
\text { memoria e a oralidade } \\
\text { dos Guarani Mbya, onde } \\
\text { os educadores indígenas } \\
\text { representam suas } \\
\text { próprias identidades } \\
\text { estabelecendo } \\
\text { ambiente um } \\
\text { autoafirmação étnica dos } \\
\text { Kyringue diante dos } \\
\text { conhecimentos } \\
\text { sabedorias antigas, e do }\end{array}$ \\
\hline
\end{tabular}




\begin{tabular}{|c|c|c|c|c|c|}
\hline & & & & & $\begin{array}{l}\text { mundo vivido por seus } \\
\text { ancestrais. } \\
\text { experiencias do } \\
\text { letramento e do mundo } \\
\text { regido pela escrita são } \\
\text { consideradas como } \\
\text { importantes } \\
\text { necessárias, no convívio } \\
\text { como não-indio e com } \\
\text { um meio de progresso } \\
\text { para os aprendizes. }\end{array}$ \\
\hline 27 & $\begin{array}{l}\text { DELLE PIAGGE, } \\
\text { A. C. M. et al. }\end{array}$ & $\begin{array}{l}\text { Reflexes acerca da } \\
\text { boneca indígena: } \\
\text { educação escolar, } \\
\text { diversidade e } \\
\text { infâncias. }\end{array}$ & 2019 & $\begin{array}{l}\text { Sistematizar } \\
\text { conhecimentos e } \\
\text { estratégias sobre a } \\
\text { utilização da boneca } \\
\text { indígena Rtixókó. }\end{array}$ & $\begin{array}{l}\text { A diversidade contribui } \\
\text { para a excelência de } \\
\text { processos educativos nas } \\
\text { práticas sociais e } \\
\text { pedagógicos, por gerar } \\
\text { espaços de convivência } \\
\text { que possibilitam tornar a } \\
\text { escola um espaço que } \\
\text { assuma as diferenças } \\
\text { existentes, construa } \\
\text { relações novas e que } \\
\text { sejam verdadeiramente } \\
\text { igualitárias, } \\
\text { compreender valores, } \\
\text { que podem fortalecer e } \\
\text { potencializar a condução } \\
\text { da vida. No entanto, criar } \\
\text { oportunidades } \\
\text { aprendizagens de } \\
\text { ensinamentos por meio } \\
\text { de bonecas plurais, } \\
\text { oportunizam a } \\
\text { construção do respeito a } \\
\text { diversidade è diferença } \\
\text { a partir da ludicidade e } \\
\text { das brincadeiras. }\end{array}$ \\
\hline 28 & $\begin{array}{l}\text { JANKAUSKAS, R. } \\
\text { M. B. et al. }\end{array}$ & $\begin{array}{l}\text { A educação infantil } \\
\text { na escola indígena } \\
\text { na comunidade de } \\
\text { Umariaçu II }\end{array}$ & 2015 & $\begin{array}{l}\text { Investigar como se dá } \\
\text { o processo de ensino } \\
\text { e aprendizagem na } \\
\text { educação infantil, na } \\
\text { escola municipal } \\
\text { AEGATU } \\
\text { DECATUCU, } \\
\text { debatendo } \\
\text { analiticamente as } \\
\text { relações indígenas e } \\
\text { não indígenas no } \\
\text { contexto educativo. }\end{array}$ & $\begin{array}{l}\text { As crianças Tikuna, tem } \\
\text { seu momento de } \\
\text { diversão, e em relação à } \\
\text { aprendizagem, res os } \\
\text { mesmos são muitos } \\
\text { atenciosos quando os } \\
\text { educadores estão a } \\
\text { explicar. Os pais não são } \\
\text { tão colaboradores da } \\
\text { educação dos filhos, } \\
\text { pois, ainda possuem a } \\
\text { ideia de que o } \\
\text { ensinamento e a } \\
\text { aprendizagem são } \\
\text { heranças marcadas e } \\
\text { enraizadas pelas } \\
\text { gerações familiares. Por } \\
\text { sua vez, para os } \\
\text { educadores a escola é a } \\
\text { instituição que tende a } \\
\text { viabilizar maitas } \\
\text { atividades para ter a }\end{array}$ \\
\hline
\end{tabular}




\begin{tabular}{|c|c|c|c|c|c|}
\hline & & & & & $\begin{array}{l}\text { presença dos pais no seu } \\
\text { cotidiano, mesmo frente } \\
\text { aos desafios que a } \\
\text { educação indígena } \\
\text { enfrenta nos currículos, } \\
\text { nos recursos, na } \\
\text { comunidade, sempre } \\
\text { com uma tendência de } \\
\text { aculturação da vida } \\
\text { social a qual a cada dia é } \\
\text { infiltrada por uma } \\
\text { sociedade mais } \\
\text { urbanizada. }\end{array}$ \\
\hline 29 & $\begin{array}{l}\text { IVES-FELIX, N. O.; } \\
\text { NAKAYAMA, L. }\end{array}$ & $\begin{array}{l}\text { A danada da escola } \\
\text { está lá: educação } \\
\text { infantil vivenciada } \\
\text { pelas crianças } \\
\text { indígenas Tentehar } \\
\text { maranhenses, a } \\
\text { partir das falas dos } \\
\text { seus interlocutores }\end{array}$ & 2018 & $\begin{array}{l}\text { Investigar o processo } \\
\text { de educação infantil } \\
\text { vivenciado pelas } \\
\text { pessoas que fazem a } \\
\text { pré-escola municipal } \\
\text { indígena Maíra-ira. }\end{array}$ & $\begin{array}{l}\text { A educação infantil } \\
\text { ainda está fortemente } \\
\text { arraigada às bases } \\
\text { epistemológicas de um } \\
\text { currículo eurocêntrico, } \\
\text { portanto, a prática do } \\
\text { professor bilingue é } \\
\text { fundamental na } \\
\text { interação professor não } \\
\text { indígena e as crianças, } \\
\text { funcionando como uma } \\
\text { porta para a valorização } \\
\text { das tradições e da lingua } \\
\text { Tentehar. A educação } \\
\text { ofertada ainda não se } \\
\text { configura plenamente } \\
\text { em um diálogo } \\
\text { contextualizado entre os } \\
\text { saberes ocidentais e os } \\
\text { tradicionais, uma vez } \\
\text { que a cultura Tentehar } \\
\text { não está sendo nem o } \\
\text { ponto de partida nem o } \\
\text { de chegada, do currículo } \\
\text { vivenciado. }\end{array}$ \\
\hline 30 & $\begin{array}{l}\text { TENÓRIO, J. G.; } \\
\text { SILVA, C. L. }\end{array}$ & $\begin{array}{c}\text { As práticas } \\
\text { corporais indígenas } \\
\text { como conteúdo da } \\
\text { educação física } \\
\text { escolar }\end{array}$ & 2014 & $\begin{array}{l}\text { Conhecer as } \\
\text { diferentes práticas } \\
\text { corporais indígenas e } \\
\text { refletir sobre sua } \\
\text { aplicação nas aulas de } \\
\text { educação física. }\end{array}$ & 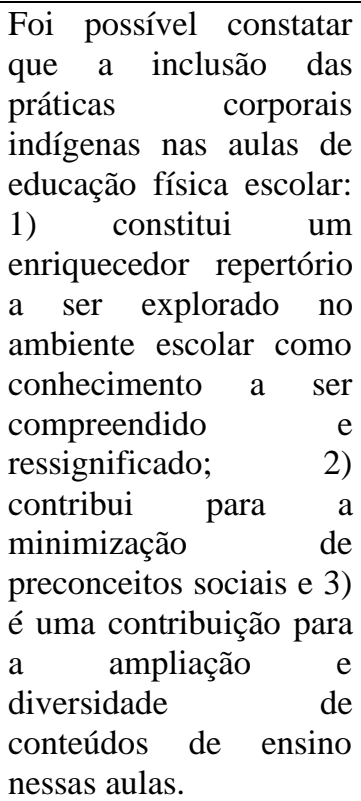 \\
\hline
\end{tabular}

Fonte: Elaborado pela autora. 
Referente à análise dos trabalhos científicos investigados o presente estudo se desdobrou na organização de três categorias gerais, conforme apresentadas a seguir.

\section{A Utilização da Ludicidade Como Recurso Pedagógico na Sala de aula}

A ludicidade (representada pelos jogos e brincadeiras) faz parte da vida da criança, sendo fundamental para $o$ desenvolvimento de sua autonomia e identidade, visto que através das brincadeiras a criança pode desenvolver a percepção, atenção e repetição.

De acordo com Santana et al (2016, p. 39), "a ludicidade está presente na vida de toda criança independentemente da época, cultura ou classe social como fator indispensável à saúde física, emocional e intelectual". Assim, quando inserida no âmbito escolar a ludicidade pode motivar o desenvolvimento da concentração, conhecimento, linguagem e a socialização ao interagir e experimentar normas e papeis sociais, "esses fatores quando bem desenvolvidos contribuirão para a eficiência e o equilíbrio da pessoa adulta" (SANTANA ET AL, 2016, p. 39).

O conceito de ludicidade e a importância do brincar vem permeando o desenvolvimento infantil e tem contribuído significativamente para aprimorar a inteligência, a socialização e as habilidades psicomotoras das crianças. Sua concepção foi variando conforme a cultura ou o período histórico no qual estava inserido.

Fazendo uma análise semântica e etimológica da palavra 'ludus' que significa jogo, Antunes e Batista (2017. p. 3) afirmam que "a evolução semântica superou suas limitações de jogo para se tornar uma atividade satisfatória e com significado, podendo ser definida conforme seu tipo, como jogo, dramatização, mimica, dança de cantiga de roda entre outras, e segundo uma teorização na área da educação".

Sob a perspectiva educacional a atividade lúdica é considerada como o berço obrigatório das atividades intelectuais da criança. Esta não é apenas uma forma de alívio ou passatempo para gastar energia das crianças, mas um meio que colabora e enriquece o desenvolvimento intelectual.

Nesse aspecto, ao ser utilizada em sala de aula, a ludicidade torna-se então um meio para a realização dos objetivos educacionais onde "os professores devem desenvolver o trabalho com materiais concretos e jogos lúdicos, onde as crianças possam manusear os brinquedos, refletir e reorganizar, sua aprendizagem, contextualizando as atividades de forma mais complexa e com mais facilidade e entusiasmo..." (ANTUNES e BATISTA, 2017, p. 4) 
Existe uma frequente associação entre a ludicidade e diversão, porém se faz necessário destacar que uma atividade lúdica não necessariamente precisa ser divertida, visto que mais importante que a diversão ou o prazer em si é a sensação de plenitude que se tem ao realizar uma atividade lúdica. Segundo Antunes e Batista (2017, p. 7) "na sala de aula o lúdico enriquece $\mathrm{o}$ aprendizado da criança $\mathrm{e}$ transforma suas ações em resultados complexos para o seu desenvolvimento enquanto aluno...". Dessa forma, a ludicidade "torna-se uma ponte que auxilia na melhoria dos resultados por parte dos educadores interessados em promover mudanças no aprendizado" (ANTUNES e BATISTA, 2017, p. 7).

Deve estar claro também, que as atividades lúdicas, incluindo jogos e brincadeiras, não apresentam uma característica universal e atemporal, pois são cingidas pela cultura e pelo momento sócio histórico em que se desenvolvem. Pode-se afirmar, então, que a cultura intermedeia todas as relações humanas e interfere significativamente em práticas sociais, rotinas, valores, costumes, linguagens, objetos e instrumentos.

A criança já nasce imersa em um mundo social e cultural e o interpreta por meio de suas experiências, de suas relações com os adultos e do ambiente em que está inserida. Para Santana et al (2016, p. 42) "o brincar está intrinsecamente no contexto cultural das crianças, pois muitas brincadeiras apresentam características do lugar onde estão situadas".

Com isso, entende-se que as experiencias lúdicas vivenciadas na infância são extremadas pelas influências culturais, o que se presume que o ato de brincar pode ser comum a todas as culturas, mas as brincadeiras e os brinquedos são distintos. Felizmente, a humanidade preservou uma intensa diversidade cultural em que é possível observar os mais variados aspectos lúdicos que desenham a infância de muitas comunidades e nações do planeta.

Nesse sentido nas palavras de Antunes e Batista (2017, p. 7), "as atividades lúdicas possibilitam a incorporação de valores, o desenvolvimento cultural, assimilação de novos conhecimentos, o desenvolvimento da sociabilidade da criatividade".

Considerando que na Educação Infantil as crianças precisam adquirir conhecimentos significativos para a sua formação, tais como: cognição, motricidade dentre outros. Compreende-se que, dependendo de como o trabalho pedagógico é desenvolvido nessas áreas a brincadeira enquanto componente escolar pode contribuir de maneira significativa no processo formativo da criança. 
Nesse contexto a brincadeira auxilia no processo de aprendizagem infantil como uma maneira do professor perceber o aluno em uma perspectiva cognitiva, afetiva, psicomotora e social. Desse modo a brincadeira pode ser vista como a ação que a criança desempenha ao concretizar as regras do jogo ao mergulhar na ação lúdica. É possível afirmar, portanto, que a brincadeira é o lúdico em ação. Antunes e Batista (2017, p. 7) afirmam que "a brincadeira também trabalha de forma gradativa o equilíbrio cognitivo das crianças contribuindo no processo de conhecimento as quais vem a apropriar-se dos signos sociais [...]".

Assim, a brincadeira torna-se a forma mais privilegiada de aprendizagem. Tendo em vista que à medida que vão crescendo, as crianças trazem para suas brincadeiras o que veem, escutam, observam e experimentam. O jogo permite a aprendizagem da criança e o seu completo desenvolvimento, já que conta com teores do dia-a-dia, como as normas, as interações com objetos e o meio e a variedade de linguagens envolvidas em sua prática.

Desse modo, fundamentando-se no pressuposto de que a prática pedagógica pode proporcionar alegria às crianças no procedimento de aprendizagem, a ludicidade deve ser levada a sério na escola, proporcionando-se o aprender por meio do jogo e, logo, o aprender brincando. Pode-se deduzir, assim que a formação lúdica do professor favorece essa prática. Segundo Luckesi (2014, p. 22), é importante que o professor "esteja internamente pleno e bem, à medida que lidera os educandos em sua aprendizagem". É possível entender que a ludicidade propicia o trabalho com diferentes linguagens, o que facilita a transposição e a representação de conceitos elaborados pelo adulto para as crianças.

Educar nessa perspectiva, é ir além da transmissão de informações ou de colocar à disposição da criança apenas um caminho, limitando a escolha ao seu próprio conhecimento. Antunes e Batista (2017, p. 10) apontam que "no processo ensinoaprendizagem cabe aos educadores proporcionar às crianças oportunidades de desenvolver as habilidades motoras fundamentais tornando-as parte importante da prática pedagógica, aperfeiçoando suas habilidades motoras [...]". Os autores afirmam ainda que através da ludicidade o professor "deve contextualizar de forma progressiva a construção das habilidades motoras, através da imagem complexa do seu corpo durante o desenvolvimento das atividades" (ANTUNES e BATISTA, 2017, p. 10)

Nesse contexto a ludicidade deve ser entendida também como recurso pedagógico tendo em vista que passa pela 
concepção de que a função educacional da escola é ensinar e que por isso está tem objetivos educacionais a atingir; a criança, nesse sentido, faz parte da elaboração e orientação rumo a esses objetivos, para chegar à constituição de seu próprio conhecimento.

Nesse sentido, dependendo de como o trabalho pedagógico é desenvolvido a Educação Física enquanto componente escolar a brincadeira pode contribuir de maneira significativa no processo formativo da criança. Para Antunes e Batista (2017, p. 12) "as propostas pedagógicas voltadas para o ensino de Educação Física apresentam-se mais diversificada nos dias atuais, embora a prática pedagógica ainda resista a mudanças". Com isso, pensar na ludicidade como recurso pedagógico para o desenvolvimento infantil, abrange questões sobre as quais os temas trabalhados nas disciplinas acadêmicas e pedagógicas permitem a articulação entre teoria e a prática. Nesse sentido, cabe ao professor conhecer a possibilidade da utilização de diferentes recursos pedagógicos em consonância com a orientação metodológica do seu trabalho.

O espaço da prática pedagógica na escola de educação infantil reflete a importância da noção teórica e prática do professor que atua em sala de aula como forma de sistematizar o conhecimento no processo de ensino-aprendizagem da criança. Nessa perspectiva, é fundamental que o professor estabeleça uma ponte entre a sua própria concepção de brincadeira, com base em suas vivências, e o conhecimento construído a partir de um sólido referencial teórico.

A ponderação sobre a prática lúdica refletida e sistematizada requer a atitude do professor em relação à pesquisa. Assim, ao pesquisar o professor perceberá que durante o processo de ensino-aprendizagem os alunos precisam adquirir conhecimentos significativos para a sua formação. E assim, na construção do saber com base no lúdico a criança enquanto participa da brincadeira, consegue elaborar metas, percebendo e explorando diferentes estímulos, e ao observar todo esse processo o professor pode antecipar alguns resultados, levantando diferentes hipóteses, formulando assim novas estratégias para a sua prática.

Diante disso, ressalta-se a necessidade de fomentar o estudo sobre a ludicidade, em especial a brincadeira, conhecendo suas classificações, identificando se uma brincadeira é ou não adequada a um determinado grupo, analisando a validade desse recurso para que seja utilizado além da recreação e do lazer. 
Acrescenta-se ainda, que as abordagens teóricas que serviram de aporte para a produção da presente categoria apontam que a ludicidade influência de forma direta na aprendizagem das crianças, possuindo assim, um papel fundamental no desenvolvimento físico-motor da criança, principalmente na atualidade, em que o tempo para brincar torna-se comprometido pelas atividades sedentárias a que a criança se vê submetida.

Também a atuação crítica da criança na sociedade, como sujeito da história, pode ser resultado da ação pedagógica por meio do lúdico, pois para a criança o espaço é o corpo vivido, descoberto e conquistado com suas próprias vivências, sendo estas a referência básica para que a brincadeira educativa pode levar o aluno à reflexão acerca de problemas sociopolíticos atuais, como ecologia, papeis sexuais, saúde, relações sociais, preconceitos sociais e raciais, discriminação contra portadores de necessidades especiais, distribuição de solo urbano, de renda etc. Isso possibilita a esse aluno o entendimento da realidade social, levando-o a interpretá-la e a explicá-la tomando por base seus interesses de classe social. Cabe à escola promover a apreensão da prática social, com base na qual os conteúdos podem ser definidos.

Nesse contexto, a brincadeira utilizada como recurso pedagógico, não é elemento que traz um saber pronto e acabado; ao contrário, esse saber precisa ser ativado pelo aluno. Assim, a brincadeira na ação pedagógica é um objeto dinâmico e que se modifica a partir das interações dos alunos.

Quando o professor tem clara a noção de que não é suficiente dar as crianças o direito de brincar, este promove também o incentivo à brincadeira, a identificação do que as leva a brincar e a reflexão sobre todo o processo do jogo. A aplicação de brincadeiras em diferentes situações educacionais é um meio para estimular, analisar e avaliar aprendizagem especificas dos alunos.

Com efeito, durante a prática pedagógica da brincadeira o professor pode perceber na criança as relações de envolvimento, autonomia e criticidade, a argumentação, o raciocínio, a memória e a linguagem. Além disso, a brincadeira envolve motivação, interesse e satisfação, ativando aspectos referentes às emoções e à afetividade, componentes importantes no processo de construção do conhecimento.

Se faz necessário ressaltar que é imprescindível repensar a formação dos educadores em educação infantil e nos anos iniciais do ensino fundamental, trazendo para os currículos de graduação a formação lúdica, para que esses profissionais atuem com conhecimento e domínio das teorias 
sobre os diversos tipos de brincadeiras, sua origem e importância pedagógica no contexto escolar, ampliando, assim, a ação educativa na sala de aula.

É indispensável que o professor possa conhecer a realidade, seu grupo de crianças, seus interesses e necessidades, comportamentos, conflitos e dificuldades e que, paralelamente, constitua um meio de estimular o desenvolvimento cognitivo,

\section{A Educação da Criança Indígena}

O direito à educação está garantido no rol dos direitos sociais elencados pela Constituição Federal (Brasil, 1988), em seu art. 60: "São direitos sociais a educação, a saúde, a alimentação, o trabalho, a moradia, o transporte, o lazer, a segurança, a previdência social, a proteção à maternidade e à infância, assistência aos desamparados, na forma desta Constituição", assim como em seu art. 205. “A educação, direito de todos e dever do Estado e da família, será promovida e incentivada com a colaboração da sociedade, visando ao pleno desenvolvimento da pessoa, seu preparo para o exercício da cidadania e sua qualificação para o trabalho". Portanto, no social, linguístico e cultural e propiciar aprendizagens especificas

Ao professor, cabe, portanto, pautarse sobre uma concepção de ludicidade que vá além de sua prática, entendendo que ela, em diversos momentos, leva o educando a discutir, refletir e explicar conteúdos, possibilitando uma gama de relações no processo ensino e aprendizagem.

Brasil, a educação torna-se, posteriormente à Carta Magna de 1988, dever do Estado e direito dos seus cidadãos.

Essa inscrição na lei é a primeira garantia para o direito, mas não ocorre de forma linear e mecânica; é fruto de lutas embasadas em uma concepção democrática de sociedade, em prol da igualdade de oportunidades e de condições sociais.

A partir da conquista da Constituição, outras leis foram sancionadas para regulamentar o direito à educação. A Lei $\mathrm{n}^{\circ}$ 9.394, de 20 de dezembro de 1996 (Brasil, 1996), estabeleceu as diretrizes e bases da educação nacional. Assim, a educação no Brasil começou a ser organizada nos seguintes níveis e modalidades de educação e ensino: 
Figura 01: Níveis e Modalidades de Ensino

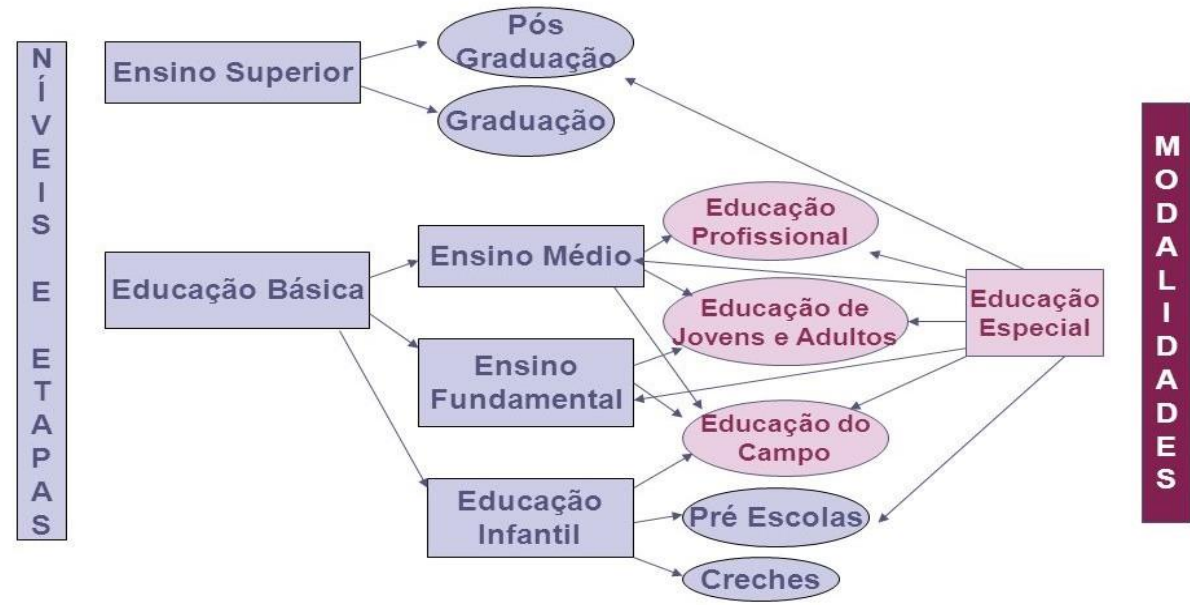

Fonte: Di Pierro (2019).

No que se refere especificamente à educação infantil, historicamente, esta desenvolveu-se lentamente e, até o presente, não tem atendido a toda demanda de crianças na faixa etária entre 0 e 5 anos de idade. A acepção contemporânea da educação infantil difere conforme aqueles que a definem. Pode-se dizer que uma nova concepção de educação infantil é formada a partir do momento em que vários grupos se apropriam de novas ideias.

Para alguns estudiosos da educação infantil há certa concordância em torno da perspectiva que determina a criança como ser adequado para interatuar e produzir cultura no meio em que se encontra. No entanto, para a sociedade formada por pais que levam seus filhos para frequentar as instituições escolares, ainda não há esse consenso, mesmo porque cada um define esse nível de educação com base em suas próprias percepções e vivências, ou seja, com base no contexto histórico e social em que vive (MENDES, 2015).

Assim, inicialmente, de acordo com a história, o atendimento a essa faixa etária não era uma competência atribuída ao setor educacional, mas surgiu associado predominantemente ao setor de assistência social, portanto, com características muito mais assistencialistas do que pedagógicas. Com isso, é possível afirmar que o início da educação infantil brasileira, está ligado à área da assistência social, com intuito por vezes filantrópico, retardou consideravelmente a preocupação com 
políticas educacionais na área (MENDES, 2015).

Somente em meados dos anos 1980 é que se firmou a ponderação a respeito do papel pedagógico das escolas que atendem crianças pequenas, Mendes (2015), afirma que a necessidade de atendimento às crianças por meio de instituições educacionais associa-se ao aumento dos centros urbanos nas cidades, bem como ao processo de inclusão das mães no mercado de trabalho devido ao processo de industrialização. Por um lado, o atendimento a essa necessidade foi uma resposta às pressões da população e, por outro lado, o próprio crescimento da sociedade capitalista (MENDES, 2015).

Acontece que nem sempre se refletiu quanto à atenção para com as crianças, ou seja, nem sempre foram inseridas em primeiro plano as possibilidades de trabalho pedagógico a serem trabalhadas com as crianças - bastava tão somente alguém que as olhasse, lhes trocasse as fraldas, as alimentasse e as colocasse para dormir. Porém, no que se refere à educação era insuficiente (MENDES, 2015).

Devido à expansão da industrialização, à crescente participação da mulher no campo de trabalho e às mudanças no ambiente familiar, houve demanda por instituições destinadas a crianças menores de 07 anos, com isso, houve também uma maior preocupação com o ensino nessas instituições (MENDES, 2015).

No início do século XX, pode-se perceber que se mantém a característica assistencialista das creches e, somente em suas décadas finais, passam a serem adotadas concepções educacionais voltadas para o desenvolvimento e a aprendizagem das crianças (MENDES, 2015).

Algumas mudanças podem ser percebidas a partir da promulgação de leis que contribuíram para a melhoria da Educação Infantil. Dentre tais leis destacam-se a Constituição Federal que aponta que todos tem o direito a educação, o Estatuto da Criança e do Adolescente de 1990 que em seu art. 15 estabelece alguns dos direitos das crianças "A criança e o adolescente têm direito à liberdade, ao respeito e a dignidade como pessoas humanas em processo de desenvolvimento e como sujeitos de direitos civis, humanos e sociais garantidos na Constituição e nas leis", e a Lei de Diretrizes e Bases da Educação Nacional (LDB) 9.394/96 que apresenta a Educação Infantil como parte da educação básica e estabelece artigos que instituem as formas de organização para o atendimento às crianças até os 05 anos de idade e ressaltam o cumprimento do direito à educação (MENDES, 2015).

Assim, com os artigos 29 e 30 da LDB 9.394/96, passa-se a considerar a 
Educação Infantil como primeira etapa da educação básica, além de estabelecer-se sua divisão em creche, responsável pelo atendimento a crianças de 0 a 03 anos, e préescola, destinada a crianças na faixa etária de 04 a 05 anos. Nesse sentido, observamse avanços se comparada essa lei com as leis vigentes anteriormente (MENDES, 2015).

Nesse ponto destaca-se a educação infantil ofertada aos povos indígenas, onde Grando (2014, p. 98) afirma que através de estudos antropológicos sobre a criança indígena brasileira, é possível compreender que "na infância indígena, a educação se dá a partir das formas como cada comunidade pensa e organiza a vida coletiva a fim de garantir o futuro das novas gerações”. Desta forma a oferta da educação para as crianças indígenas "é opcional, cabendo a cada comunidade indígena decidir sobre seu oferecimento” (TROQUEZ, 2016, p. 80).

A autora destaca ainda que "a oferta da educação infantil deve considerar as especificidades e os direitos à diferença e à autodeterminação dos povos indígenas, bem como a participação da comunidade no processo" (TROQUEZ, 2016, p. 80).

Muitos historiadores relatam que o processo de transmissão dos saberes às crianças nas comunidades indígenas é pautado inicialmente pela observação e imitação, assim, nas palavras de Silva (2014, p. 658), a educação infantil indígena é considerada "comunitária", que ocorre "principalmente através da intensa participação das crianças na vida da aldeia, integrada nas atividades cotidianas e rituais de seu grupo, como se toda a ação presente fosse considerada exemplar e modelar".

Silva (2014, p. 664) afirma que a participação da criança é iniciada logo cedo, assim que ela começa a andar, realizando algumas tarefas da casa, assim,

'[...] Quase sempre elas testemunham as atividades realizadas na casa ou no quintal, mantendo proximidade com as pessoas que as executam, mas apenas observando-as. A observação por parte das crianças constitui-se em uma característica muito forte no grupo".

Acerca desse convívio entre os adultos e o aprendizado comunitário Grando (2016, p. 90) afirma que "as crianças têm a liberdade de experimentar as atividades dos adultos e nisso são respeitadas, no entanto a aprendizagem é sempre uma iniciativa da criança, e a correção dessas aprendizagens não é feita de forma incisiva, mas no tempo próprio de cada criança".

Esse tipo de educação é conhecido comumente como educação informal, que ocorre fora das instituiçõos escolares, mais 
precisamente no ambiente familiar e cultural, sem a presença de técnicas pedagógicas.

Entende-se com isso, que sob a perspectiva da educação indígena, a criança aprende conhecendo, vivenciando o cotidiano da aldeia e, mais que isso, seguindo a vida dos mais experientes, imitando, inventando, idealizando, sendo que o clima familiar, formado pelo conjunto de consanguinidade, proporciona a autonomia e liberdade imprescindíveis para essa aprendizagem infantil.

A importância dessa aprendizagem informal fundamenta-se no fato de que a transmissão de regras de comportamento socia, de domínio do mundo material e espiritual, tudo isso era passado através de um ensinamento baseado no dia a dia, variado em suas formas, mas substantivo.

Dessa forma os índios adultos transmitiam às crianças os conhecimentos para que pudessem fazer um vaso de cerâmica, um artefato de pedra ou de madeira, de modo que aprendessem a caçar, pescar, lutar em guerra. Essa educação dos cinco sentidos (olfato, tato, paladar, visão e audição) era dada através do gesto técnico, que consistia na capacidade humana, de por meio de gestos observados e aprendidos de manejar e modificar os objetos.

Para uma criança não índia pode não ser uma tarefa fácil fazer um arco e flecha, uma canoa ou moldar e cozer um vaso de barro, no entanto para uma criança indígena ao observar diariamente essas atividades, tornava-se simples e comum executá-las. Por isso, a observação e imitação era algo importante no processo de aprendizagem entre os índios, tendo em vista que não havia cursos nem cartilhas explicativas, mas sim a transmissão da gestualidade que permitia a que a vida diária se perpetuasse.

Além da gestualidade a oralidade também se destaca como forma de transmissão de conhecimento na educação infantil indígena, onde a palavra dos índios mais velhos se faz presente na vida cotidiana, e com isso as crianças aprendiam sobre os costumes indígenas, como afirmam Bergamaschi e Menezes (2016, p. 751), "não apenas na fala, mas na escuta respeitosa e atenta: escutar e entoar os cantos e se dispor ao ensinamento que é oferecido pela palavra são marcas importantes nos processos próprios de aprendizagem".

Embora a educação informal ainda se faça presente em muitas comunidades indígenas, o reconhecimento de que esses povos são portadores de especificidades políticas e culturais e que tem o direito de viver conforme suas próprias referencias e decidir sobre seu futuro trouxe consequências diretas à política educacional. Desse modo, a criação da categoria 'escola indígena' dentro dos sistemas de ensino, consistiu num grande 
avanço em comparação aos padrões anteriores, embora não contemple totalmente as expectativas dos povos indígenas.

Essa nova realidade da criança indígena inserida em um sistema de ensino, ao vivenciar outras experiências no sistema de ensino embora se apresente como uma perspectiva promissora, aponta certo conflito existente, tendo em vista que "as crianças indígenas recebem desde $\mathrm{o}$ nascimento, o ensinamento dos mais velhos no sentido da preparação para uma vida indígena futura, o que se aprende na escola pode estar sendo conflitante com a que lhes é culturalmente oferecido" (JANKAUSKAS et al, 2015, p. 02).

Entretanto, estes conflitos culturais que as crianças indígenas vivenciam possibilita uma condicionalidade característica e cultural, nesse sentido, a transformação identitária determinada pelos conflitos, não é compreendida pela criança indígena, que ao ser inserida em uma instituição escolar tende a negar e/ou esquecer sua cultura, perdendo parte da referência segura que a faz relacionar-se socialmente entre a cultura indígena e não indígena.

Assim, considerando que as crianças indígenas aprendem brincando e atuando juntamente com a comunidade em que está inserida, apreendendo os saberes dos índios mais velhos, pode-se afirmar que a educação escolar infantil indígena "precisa ser pensada a partir da identidade sociocultural de cada povo, constituindo-se a continuidade da educação tradicional oferecida na e pela família, e, nesse aspecto, é que reside o específico e diferenciado na educação intercultural" (IVES-FELIX e NAKAYAMA, 2018, p. 43).

Como se sabe a educação intercultural é compreendida como uma prática social que se relaciona intensamente com as dinâmicas distintas da comunidade escolar. Relacionando tal concepção de educação intercultural com a realidade da educação indígena, percebe-se que "no campo da educação escolar indígena, diferentes interpretações acerca da interculturalidade e/ou diálogo intercultural enquanto proposta e projeto educativo têm causado muitas controvérsias" (Nascimento, Quadros e Fialho, 2016, p. 196). Uma vez que ao refletir sobre a inserção da interculturalidade no dia a dia das escolas indígena supõe-se que o modelo de educação assimilacionista será trocado por um modelo de educação voltado especificamente para os povos indígenas, porém se percebe que o modelo de educação assimilacionista predomina os currículos de muitas indígenas.

Nascimento (2017, p. 385) afirma que é possível perceber no currículo das escolas indígenas "um conjunto de 
demandas que aludem ao problema do reconhecimento na esfera pública em face das situações de preconceito e reclamam o direito à diferença, negado no modelo já referido da educação escolar para os indios". Assim, o questionamento a respeito de um currículo específico para as escolas indígenas se faz necessário, no contexto da necessidade de atendimento à educação diferenciada.

Nesse sentido Nascimento (2017, p. 385) afirma que, "a percepção dos indígenas sobre o papel da escola diferenciada está ligada às disputas simbólicas - e também materiais, uma vez que são reivindicados recursos específicos que constituem as políticas de educação escolar indígena".

Dessa forma entende-se que é necessário que as crianças indígenas se apropriem dos conhecimentos exteriores, porém, é fundamental defender a ideia da inserção de conhecimentos indígenas no currículo escolar, considerando que esses podem sem escolarizados, sendo apropriados para a educação escolar indígena. Com isso ao se pensar em um currículo específico na Educação Escolar Indígena é preciso falar de sua flexibilidade, no sentido de que esteja sempre aberto, e adequado à realidade de cada comunidade.

Existem políticas públicas que garantem a construção dessa especificidade curricular para as escolas indígenas, conforme se observa no artigo 78 da LDB 9.394/96, onde se estabelece que se deve “desenvolver currículos e programas específicos, neles incluindo os conteúdos culturais correspondentes às respectivas comunidades" (BRASIL, 2018, p. 34).

É possível mencionar ainda as Diretrizes Curriculares Nacionais para Educação Escolar Indígena, onde consta em seu art. $8^{\circ}$, que as escolas que ofertam a educação às crianças indígenas devem " $\$ 3^{\circ}$ III - considerar as práticas de educar e de cuidar de cada comunidade indígena como parte fundamental da educação escolar das crianças de acordo com seus espaços e tempos socioculturais" (BRASIL, 2012, p. 4). O mesmo documento acrescenta ainda, que tais escolas precisam "IV - elaborar materiais didáticos específicos e de apoio pedagógico para a Educação Infantil, garantindo a incorporação de aspectos socioculturais indígenas significativos e contextualizados para a comunidade indígena de pertencimento da criança" (BRASIL, 2012, p. 4).

Nesse contexto, a inserção da criança indígena no sistema de ensino regularizado permite iniciar um novo ciclo de aprendizagem onde ela será exposta à diversas ferramentas de sistematização de conhecimentos, o que possibilita com isso, compreender e dominar os saberes 
indígenas associando-os com os saberes não indígenas.

\section{A Ludicidade na Educação Infantil Indígena}

A Educação Infantil é uma etapa fundamental da Educação Básica, onde a construção do espaço e da identidade da criança é feita à medida que são efetivadas as políticas de atendimento. Nesse período a utilização da ludicidade durante as aulas pode gerar oportunidades de aprendizagem, incluindo $\mathrm{o}$ respeito à diversidade e a formação da identidade. Assim, a escola pode proporcionar um ambiente lúdico para a aprendizagem significativa, embora muitas vezes não é nesse cenário que a aprendizagem ocorre.

De acordo com Teixeira (2018, p. 141) "o pano de fundo que se descortina em muitas realidades educacionais brasileiras é a intercorrência de uma aprendizagem mecânica, baseada na memorização e em metodologias que não se contextualizam com atividades práticas do dia a dia e que não refletem a realidade da infância". Assim, para que a aprendizagem escolar seja significativa é necessário que ocorra uma interação entre os conhecimentos prévios e os novos conhecimentos, com a utilização de um modelo de aprendizagem menos engessado, mais dinâmico, relacionando as práticas cotidianas e com foco na resolução de problemas. Nesse sentido, os aspectos lúdicos, ganham um significado especial.

A atividade lúdica em si, no entanto, nem sempre gera aprendizagem. Ela precisa de intervenção do educador, de forma planejada e intencional. Um educador comprometido com a aprendizagem dos alunos não deve focar em seu trabalho, somente a memorização; ele precisa vivenciar uma prática que tenha significado para o aluno. As brincadeiras e os jogos comumente fazem parte da rotina dos alunos e, aliados aos demais aspectos lúdicos, como a literatura, os desenhos, a música, a dramatização e a arte como um todo, promovem resultados mais produtivos para a aprendizagem.

Segundo Mota e Ramires (2018, p. 2), "a realidade educacional das instituições de educação infantil comporta a necessidade de uma prática pedagógica lúdica que venha respeitar o processo de aprendizagem das crianças indígenas e não indígenas". No que se refere ao aprendizado das crianças indígenas pode-se afirmar que estas aprendem imitando os costumes do cotidiano na comunidade, conforme aponta Figueiredo e Azevedo (2014, p. 139), “o aprendizado da criança, nas etnias indígenas, começa na imitação dos habitus, 
brincadeiras que imitam as tarefas femininas".

Nesta perspectiva a ludicidade permite à criança indígena a imitação de diversos papeis, usualmente do seu dia a dia, ato que promove a expressão de sentimentos e relações que estabelece, com as pessoas do meio. A imitação também é um elemento que garante à criança indígena experimentar atitudes que permite desenvolver habilidades e valores importantes, "como, por exemplo, a preparação de alimentos - o biju; as crianças desenvolvem objetos, como as primeiras cestas de fibras para as meninas e a confecção dos pequenos arcos e flechas para os meninos, fazendo da própria natureza física seu momento de experiências" (FIGUEIREDO e AZEVEDO, 2014, p. 139). Dessa forma, quando brinca de faz de conta, imitando as tarefas dos índios adultos, a criança age e enfrenta desafios, organiza o pensamento e elabora suas regras, o que facilita a transposição do mundo adulto para o seu universo.

De acordo com o Referencial Curricular Nacional para Educação Infantil "a brincadeira favorece a autoestima das crianças, auxiliando-as a superar progressivamente suas aquisições de forma criativa. Brincar contribui, assim para a interiorização de determinados modelos de adultos, no âmbito de grupos sociais diversos" (BRASIL, 1998, p. 27). É possível entender com isso, que a brincadeira propicia o trabalho com diferentes linguagens, o que facilita a transposição e a representação de conceitos elaborados pelo adulto para as crianças.

A brincadeira permite ainda a potencialização da aprendizagem e do desenvolvimento da criança através da interação com outras crianças e com os adultos. Nesse sentido, segundo a Base Nacional Comum Curricular (BNCC), “interação durante o brincar caracteriza o cotidiano da infância, trazendo consigo muitas aprendizagens e potenciais para o desenvolvimento integral das crianças" (BRASIL, 2017, p. 37), e acrescenta ainda que, "ao observar as interações e a brincadeira entre as crianças e delas com os adultos, é possível identificar, por exemplo, a expressão dos afetos, a mediação das frustrações, a resolução de conflitos e a regulação das emoções" (BRASIL, 2017, p. $37)$.

A fim de facilitar esse processo a BNCC estabeleceu seis direitos de aprendizagem e desenvolvimento que “asseguram, na Educação Infantil, as condições para que as crianças aprendam em situações nas quais possam desempenhar um papel ativo em ambientes que as convidem a vivenciar desafios e a 
sentirem-se provocadas a resolvê-los, nas quais possam construir significados sobre si, os outros e o mundo social e natural"
(BRASIL, 2017, p. 37), conforme se pode observar no quadro abaixo:

Quadro 02: Direitos de Aprendizagem e Desenvolvimento na Educação Infantil

Conviver com outras crianças e adultos, em pequenos e grandes grupos, utilizando diferentes linguagens, ampliando o conhecimento de si e do outro, o respeito em relação à cultura e às diferenças entre as pessoas.

Brincar cotidianamente de diversas formas, em diferentes espaços e tempos, com diferentes parceiros (crianças e adultos), ampliando e diversificando seu acesso a produções culturais, seus conhecimentos, sua imaginação, sua criatividade, suas experiências emocionais, corporais, sensoriais, expressivas, cognitivas, sociais e relacionais.

Participar ativamente, com adultos e outras crianças, tanto do planejamento da gestão da escola e das atividades propostas pelo educador quanto da realização das atividades da vida cotidiana, tais como a escolha das brincadeiras, dos materiais e dos ambientes, desenvolvendo diferentes linguagens e elaborando conhecimentos, decidindo e se posicionando.

Explorar movimentos, gestos, sons, formas, texturas, cores, palavras, emoções, transformações, relacionamentos, histórias, objetos, elementos da natureza, na escola e fora dela, ampliando seus saberes sobre a cultura, em suas diversas modalidades: as artes, a escrita, a ciência e a tecnologia.

Expressar, como sujeito dialógico, criativo e sensível, suas necessidades, emoções, sentimentos, dúvidas, hipóteses, descobertas, opiniões, questionamentos, por meio de diferentes linguagens.

Conhecer-se e construir sua identidade pessoal, social e cultural, constituindo uma imagem positiva de si e de seus grupos de pertencimento, nas diversas experiências de cuidados, interações, brincadeiras e linguagens vivenciadas na instituição escolar e em seu contexto familiar e comunitário. Fonte: Brasil (2017, p. 38).

\section{É possível perceber como a BNCC} ressalta o direito de brincar da criança e desse modo, entende-se que para considerar e executar os direitos da aprendizagem e desenvolvimento apontados pela BNCC, se faz necessário tê-los sempre em mente garantindo assim que os conhecimentos propostos estejam em conformidade com os aspectos básicos.

Nesse sentido, em relação ao conhecimento sobre a brincadeira na educação infantil indígena, o educador que optar em utilizar as brincadeiras como recurso pedagógico pode partir da reflexão sobre como o lúdico está presente no cotidiano infantil indígena. Assim, é preciso que se delimitem esforços para garantir à criança indígena um espaço que possibilite a ação lúdica, ou seja, um ambiente no qual ela tenha a oportunidade de escolher os jogos, os materiais e o modo de explorar e criar suas brincadeiras.

Nesse período em que a criança é inserida no ambiente escolar, sabe-se que do mesmo modo que há a interação com os outros, e a linguagem oral, há também um grande desenvolvimento físico-motor, que possibilita uma mudança significativa nas relações com o mundo. Desse modo, a criança vai desenvolvendo movimentos que 
lhe permitem uma atuação mais autônoma no seu meio, tanto em relação às possibilidades de deslocamento, quanto na perspectiva do autocuidado.

Entende-se que o desenvolvimento dos movimentos é muito significativo para a criança indígena, tendo em vista que "as práticas corporais, nas sociedades indígenas, constituem bens culturais que refletem suas tradições e comportamentos" (TENÓRIO e SILVA, 2014, p. 89). Assim, a corporalidade é considerada "como o processo de construção e linguagem expressiva [...]" (FIGUEIREDO e AZEVEDO, 2014, p. 138).

Ao trabalhar a corporeidade na educação infantil, permite-se que a criança se aproprie dos gestos e do repertório de atividades culturais relacionados ao movimento, que lhe permitem a realização de ações e procedimentos, bem como compreender e expressar ideias, sentimentos e desejos. Essas apropriações ocorrem nas relações sociais e afetivas com os sujeitos da cultura e nas relações que ela estabelece com a natureza, que ela estabelece com a natureza, constituindo-a como sujeito nesse mundo social e natural.

Tendo em vista que essas são aquisições das crianças, principalmente na faixa etária de 0 a 6 anos, evidencia-se a importância do trabalho desenvolvido nas instituições de Educação Infantil, no sentido de favorecer às crianças a construção de sua corporeidade.

Uma das maneiras mais significativas de favorecer esse processo na educação infantil indígena, é possibilitar que as crianças vivenciem jogos e brincadeiras, principalmente nos espaços externos da escola, onde possam explorar as possibilidades do seu próprio corpo, tocar o corpo dos colegas, expandir seus movimentos, correndo, pulando, subindo, rolando, balançando, escorregando, empurrando pneus ou outros objetos, brincando na água etc.

Mesmo nos espaços internos, em vez de manter as crianças por longo tempo nos berços ou sentadas nas mesinhas, o professor pode organizar espaços e materiais que permitam a vivência do corpo no espaço, como tuneis, rampas, obstáculos, colchões, almofadas, caixas grandes de papelão, ou mesmo pode transformar as mesinhas e cadeiras de sala em ônibus, cavernas, cabanas, trampolins para mergulhar nos colchões que viram 'rios, piscinas ou praias'.

Segundo Barros et al. (2014, p. 40) como "o brincar, é uma atividade dominante no modo de vida das crianças na aldeia, é preciso ampliar o seu significado na escola indígena, a partir da reflexão e da interação dos professores indígenas ou não, tornando possível o desenvolvimento de 
ações que levam à significação e a ressignificação do fazer pedagógico a partir do brincar". Com isso, é importante ressaltar que as experiências vivenciadas pelas crianças indígenas na escola precisam favorecer, ao mesmo tempo, o desenvolvimento da corporeidade, da capacidade de compartilhar significados, sentimentos, e de imaginar, na medida em que acabam por se constituir em jogos dramáticos, danças e imitações que exploram a gestualidade e a linguagem cênica.

Essas propostas vão no sentido contrário daquelas que artificializam e padronizam as possibilidades de expressão corporal e imaginativa das crianças, por meio de apresentações de 'teatrinhos' e 'dancinhas' que são exaustivamente treinados, ensaiados, com o intuito único de as crianças se mostrarem aos pais e a outros adultos. Elas se contrapõem também àquelas propostas escolarizantes que, em vez de trazer a compreensão da corporeidade se realiza na interação com o outro em vivências significativas do corpo no espaço, refletem a concepção de que as crianças aprendem por meio da repetição e do treinamento.

É fundamental que em todas as suas ações o professor esteja atento, na sua prática pedagógica, à construção da autoestima pelas crianças e ao desenvolvimento de atitudes de respeito, confiança, cooperação e tolerância no grupo. Nesse contexto, a contação de histórias, além de estimular a imaginação das crianças, em um clima de alegria e descontração, permite que as atitudes anteriormente mencionadas sejam desenvolvidas. Para Figueiredo e Azevedo (2014, p. 140), “ouvir e contar histórias são uma prática que, desde muito cedo, através de narrativas, transmitem o imaginário povoado de figuras que ligam o universo cultural do índio a seus entes míticos. Assim, perpetuam a memória e a cultura de seu povo no inconsciente das crianças. Elas aprendem a reconhecer a si e aos outros", e assim outros objetivos podem ser alcançados tais como educar, instruir desenvolver a capacidade intelectual delas.

Dessa forma, as histórias podem ser usadas tanto como ponto de partida para ensinar determinados conteúdos programáticos quanto como instrumento que facilita a compreensão do comportamento das crianças no campo pessoal.

É sabido que contar histórias é uma das mais antigas artes encontradas nas mais diversas nações, sendo que historicamente, a função social do conto representou diferentes papéis de acordo com a cultura e as características destas sociedades. Tal arte está ligada à essência do ser humano tanto 
que as narrativas tradicionais expressam, em imagens, as verdades mais profundas da vida, e por isso, se tornam eternas.

O contador de histórias tinha grande importância social e cultural no passado, sendo considerado uma espécie de depositário da experiência, do conhecimento e da sabedoria de sua época. Posteriormente, essa arte adquiriu status de rito familiar que, possibilitava a criação de clima mais íntimo, favorável à relação entre as gerações. Diante disso pode-se perceber, portanto, que o processo da contação de história, por ser uma arte antiga, associa-se com a história da nossa própria cultura, a cultura humana. Figueiredo e Azevedo (2014, p. 140) afirmam que "os contadores de histórias passam para os jovens muito mais que narrativas, eles sedimentam alicerces para novas posturas e isso é educar".

Com isso, a história contada pode ser fundamentada tanto na formação educativa quanto na formação cultural da criança, tendo em vista que o conto infantil supre a necessidade da curiosidade e descoberta que a criança possui.

Embora o atrativo inicial dos contos seja o de entreter e encantar, seu valor principal fundamenta-se no poder de ajudar as crianças a lidar com os conflitos internos, que se apresentam no processo de crescimento. Em consequência desses aspectos, os contos também oferecem às crianças um palco, no qual elas podem representar seus conflitos interiores.

Diante dessa constatação torna-se fácil perceber a importância das histórias contadas no cotidiano escolar. Entretanto, não basta tão somente ler uma história em sala de aula. Além de uma boa história, que deve ser escolhida de acordo com a faixa etária da criança, e do próprio desempenho do contador, ainda há de se utilizar de materiais ilustrativos para despertar o interesse infantil.

Assim ao ler uma história é preciso chamar a atenção da criança usando diferentes recursos, mostrando a ela que ler não é apenas um ato que se transforma em hábito, mas sim uma importante ferramenta na formação de pessoa, onde envolve a cultura e a forma de compreender e entender o mundo.

Considerando que os contos podem ser utilizados no cotidiano escolar de forma relacionada à concepção de infância que permeia o discurso pedagógico percebe-se a necessidade de resgatar o prazer da leitura, bem como, da contação de histórias, estimulando assim a inteligência, discutindo valores, permitindo a exploração da criatividade, imaginação e da socialização.

Nesse contexto, é importante que o educador reflita sobre como a utilização da contação de história, ainda que considerada 
como brincadeira pode contribuir para o desenvolvimento do potencial criativo dos alunos, apresentando desafios de valor sociocultural em uma perspectiva mais dinâmica. Mota e Ramires (2018, p. 8) afirmam que, "faz-se necessário que o professor compreenda a criança indígena como um sujeito produtor de cultura, como um ser social pleno e diferenciado inserido

\section{CONCLUSÃO}

A ludicidade tem um papel fundamental na Educação Infantil, tendo em vista que ela possibilita e proporciona às crianças diversas experiências através de contextos nas quais elas possam criar, inventar, se descobrir, elaborar conceitos e ideias sobre o movimento e suas ações. Essa ferramenta quando utilizada nas aulas da Educação Infantil Indígena pode ser considerada como um recurso pedagógico promissor.

Nesse contexto, considerando que a brincadeira é um instrumento pedagógico muito significativo e de grande valor social, o presente trabalho foi realizado através de uma revisão sistemática integrativa, objetivando analisar a concepção da ludicidade a fim de compreender os caminhos construídos para essa prática na educação infantil indígena.

Com esta pesquisa evidenciou-se através das teorias dos autores estudados em um contexto sociocultural com suas peculiaridades", por isso, quando uma criança indígena começa frequentar uma instituição escolar é importante que o professor reconheça e valorize os conhecimentos prévios que ela obteve na comunidade indígena, associando-os aos novos conhecimentos, através de uma prática lúdica e afetiva.

que o ato de jogar e brincar além de estimular a imaginação das crianças indígenas atinge outros objetivos como permitir que as crianças possam experimentar vários aspectos da vida, encarando assim emoções conflitantes quando representadas à vida real. A ludicidade apresenta-se, portanto, como um recurso pedagógico que oportuniza conhecer a realidade dos seus alunos, seus interesses e necessidades, comportamentos, conflitos e dificuldades, bem como educar, instruir e desenvolver a capacidade intelectual delas.

O breve histórico apresentado apontou como a educação tem evoluído ao longo do tempo, onde se percebeu a busca de uma educação de qualidade para as crianças indígenas. A ludicidade passa, então, a adquirir um sentido mais abrangente, sendo compreendida como um recurso pedagógico que se presta ao diagnóstico do processo de aprendizagem infantil como uma maneira do professor 
perceber o aluno em uma perspectiva cognitiva, afetiva, psicomotora e social.

Nesse contexto o professor surge como peça fundamental, agindo como mediador entre a criança e o conhecimento, tendo em vista que não basta a criança jogar e brincar se não souber agir sobre os jogos e as brincadeiras.

Fundamenta-se, portanto, a importância da utilização da ludicidade como recurso pedagógico na educação

\section{REFERÊNCIAS}

ALMEIDA, J. A. et al. Infância e educação infantil indígena: um estudo da criança Apinajé. Facit Business and Tecnology Journal. 2 (1), p. 103-118, 2017.

ANDRIOLLI, L. R.; GAUSTINO, R. C. Vivências de crianças indígenas Kaingang na cidade: elementos para a aprendizagem e o desenvolvimento. Revista

Humanidades e Inovação. v. 6, n. 15, 2019.

ANTUNES, P.; BATISTA, F. M. R. Brincar de aprender; a ludicidade como recurso didático na educação infantil. R. Eletr: Cient. Inov. Tecnol., Medianeira, v. 8, n. 17, 2017.

BARROS, J. C. et al. O brincar das crianças Sataré-Mawé e suas relações interculturais com a educação escolar indígena. RPCD, Universidade Federal do Amazonas, Manaus, 14 (1): 26-48, 2014.

BERGAMASCHI, M. A.; MENEZES, A. L. T. Crianças indígenas, educação, escola e interculturalidade. Revista ecurriculum, v. 14, n. 2, abril./jul, p. 741764, 2016. infantil indígena, uma vez que ela supre a necessidade da curiosidade e descoberta que a criança possui. Considerando que esta utilização, quando trabalhada de forma adequada, pode ser fundamentada tanto na formação educativa, quanto na formação cultural da criança indígena, entende-se que esta prática se torna, indiscutivelmente necessária no processo ensinoaprendizagem.

\section{BRASIL. Base Nacional Comum}

Curricular: Educação Infantil e Ensino Fundamental. Brasília: MEC/Secretaria de Educação Básica, 2017.

Diretrizes Curriculares

Nacionais para a Educação Infantil Brasília, DF: Ministério da Educação, 2009.

LDB: Lei de diretrizes e bases da educação nacional. - 2. ed. - Brasília: Senado Federal, Coordenação de Edições Técnicas, 2018.

Ministério da Educação e do

Desporto. Referencial Curricular Nacional para Educação Infantil. Brasília: DF: MEC, 1998. Vol. 1.

CONTI, K. C. et al. Criação de jogos no contexto indígena: o cabo de guerra numérico. Polyphonía. v. 28/2, jul./dez. 2017.

Uso de jogos matemáticos como proposta pedagógica num contexto de formação intercultural para professores indígenas. Cadernos Cenpec. São Paulo, v. 8, n. 1, p. 180-206, jan./jul. 2018.

DELLE-PIAGGE, A. C. M. et al. Reflexões acerca da boneca indígena: educação escolar, diversidades e infâncias. 


\section{Revista Eletrônica da Educação,}

Releduc, v. 2, n. 2, ago, 2019.

DI PIERRO, M. C. A organização do sistema de ensino brasileiro. Disponível em: <

https://slideplayer.com.br/slide/293758/>

Acesso em: 20 de novembro de 2019.

DOMINGUES-LOPES, R. C. et al. O lúdico em questão: brinquedos e brincadeiras indígenas. Desidades, v. 6 , Rio de Janeiro, mar. 2015.

FAUSTINO, K. C.; MOTA, L. T. Crianças indígenas: o papel dos jogos, das

brincadeiras e da imitação na aprendizagem e no desenvolvimento. Acta Scientiarum Education, Maringá, v. 38, n. 4, p. 395-404, oct./dec. 2016.

FIGUEIREDO, L. M. S.; AZEVEDO, L. F. Jogos e brincadeiras indígenas em Mato Grosso. Unopar Cient. Ciênc. Human. Educ., Londrina, v. 15, n. 2, p. 137-141, jun, 2014.

GODOY, M.; FERREIRA, E. O universo cultural da criança Guarani Mbya e a presença dos centros educacionais e culturais indígenas, Cecis, nas aldeias de Saõ Paulo. Cadernos CERU, 25 (1), P. 101-120, 2014.

GRANDO, B. S. Infância, brincadeiras e brinquedos em comunidades indígenas brasileiras. Revista Aleph. Ano XI, n. 22, dezembro, 2014.

Educação da criança indígena e educação infantil em Mato Grosso: uma questão para o debate. Tellus, Campo Grande, MS, ano 16, n. 31, jul./dez. 2016. IVES-FELIX, N. O.; NAKAYAMA, L. A danada da escola está lá: educação infantil vivenciada pelas crianças indígenas Tentehar maranhenses, a partir das falas dos seus interlocutores. Tellus, Campo Grande, MS, ano 18, N. 36, P. 39-66, maio/ago. 2018.
JANKAUSKAS, R. M. B. et al. A educação infantil na escola indígena na comunidade de Umariaçu II. VII FIPED Fórum Internacional de Pedagogia, Parintins, AM. v. 1, 2015.

LUCKESI, C. Ludicidade e formação do educador. Revista entre ideias, Salvador, v. 3, n. 2, p. 13-23, jul./dez. 2014.

MARTINS, R. et al. O resgate das memorias do jogo e brincadeiras de uma comunidade indígena. Athlos - Revista Internacional de Ciencias Socialies de La Actividad Física, el Juego y el Deporte. v. XVI - ano VIII, Enero, 2019.

MELO, A.; RIBEIRO, D.

Interculturalidade e educação infantil: reflexões sobre diferenças culturais na infância. Conjectura: Filos, Educ., Caxias do Sul, RTS, Ahead of Print, v. 24, e019039, 2019.

MELO, J. C. A função do lúdico na transição da educação infantil para o primeiro ano do ensino fundamental. Revista Humanidades e Inovação. v. 6, n. 15, 2019.

MENDES, S. L. Tecendo a história das instituições do Brasil infantil. SABERES, Natal-RN, v. 1, n. 11, p. 94-100, Fev. 2015.

MOTA, L. K. L.; RAMIRES, C. R. Educação infantil indígena e a ludicidade: a percepção de agentes escolares na aprendizagem da criança. III Seminário Internacional em Sociedade e Cultura no Pan-Amazônica. Universidade Federal do Amazonas-UFAM, Manaus, 21 a 23 de novembro, 2018.

NASCIMENTO, R. G. Escola como local das culturas: o que dizem os índios sobre escola e currículo. Revista Educ. Public. Cuiabá, v. 26, n. 62/1, p. 373-389, maio/ago. 2017. 
NASCIMENTO, R. N. F.; QUADROS, M. T.; FIALHO, V. Interculturalidade enquanto prática na educação escolar indígena. Revista Antropológicas, 27 (1): 187-217, 2016.

PINHO, V. A.; TOMAZZETTI, C. M. Infâncias, saberes e diversidade: um diálogo com a educação infantil. Revista

Educ. Públ., Cuiabá, v. 26, n. 62/2, p. 617638, maio/ago, 2017.

PORTO, S. G. S. Ludicidade: um caminho para ressignificar a prática pedagógica e o desenvolvimento da criança na educação infantil. Revista Cientifica Multidisciplinar núcleo do conhecimento. Ano 03, ed. 08, v. 12, p. 72-83, agosto de 2018.

RAMIRES, C. R.; MOTA, L. K. L. Educação infantil indígena e a formação de professores: aspectos legais e a importância da qualidade educacional préescolar na voz docente. III Seminário Internacional em Sociedade e Cultura no Pan-Amazônica. Universidade Federal do Amazonas-UFAM, Manaus, 21 a 23 de novembro, 2018.

RODRIGUES, W. Relacionando ludicidade e matemática na infância indígena. Revista Didática Sistêmica. V. 20, n. 2, p. 120-130, 2018.
SANTANA, F. M. N. et al. Ludicidade e o contexto cultural diversificado: contribuições e desafios no processo ensinar e aprender. Revista Diálogos Interdisciplinares - GEPFIP.

Aquidauana, v. 1, n. 3, p. 37-49, dez. 2016.

SILVA, M. et al. Brinquedos e brincadeiras indígenas Kaingangs: transfiguração entre gerações. Revista Mackenzie de Educação Física e Esporte. v. 14, n. 2, p. 54-61, 2015.

SILVA, R. C. Participação e aprendizagem na educação da criança indígena. Revista brasileira de Educação. v. 19, n. 58, jul./set. 2014.

TEIXEIRA, K. L. O universo lúdico no contexto pedagógico. Curitiba:

Intersaberes, 2018. (Série Panoramas da Psicopedagogia).

TENÓRIO, J. G.; SILVA, C. L. As práticas corporais indígenas como conteúdo da educação física escolar. Revista Teoria e Prática da Educação. v. 17, n. 1, p. 81-91, janeiro/abril, 2014.

TROQUEZ, M. C. C. Educação infantil indígena na legislação e na produção do conhecimento. Horizontes - Revista de Educação. Dourados, MS, v. 4, n. 7, janeiro a junho, 2016. 